\title{
The Civilian Law of Delict: A Comparative and Historical Analysis
}

\author{
Gert Brüggemeier \\ Professor Emeritus of Civil Law and Comparative Law, Law Faculty, \\ University of Bremen, Germany \\ gbruegge@uni-bremen.de
}

\begin{abstract}
This article explores the civilian tradition of the European law of delict. Part 1 tells the story of the birth of modern civil law of delict in the 19th century codifications in continental Europe, rooted in Roman law and Enlightenment Natural Law. Examples are the French and German codes, and the Japanese as a legal transplant. Fault, unlawfulness (Rechtswidrigkeit), damage, and causation are the central categories. Part 2 focuses on the challenges of industrialisation: enterprises as new actors, industrial accidents, technical risks, insurance. This part discusses the changes the civil law of delict and the common law of torts underwent to cope with these challenges. Part 3 draws some consequences from these developments. It outlines the basic structures of a postmodern civil law of delict, explicitly differentiating it from the law of torts, and as a basis for further developments in 21st century. This structure has three main features: liability for personal fault, liability for defective business activities, and Gefährdungshaftung.
\end{abstract}

\section{Keywords}

delict - civil law - German law - French law - Japanese law - torts - common law enterprise liabilitly - intentional injury - negligence - Gefährdungshaftung 
The modern European law of delict evolved from the national civil law codifications of the $19^{\text {th }}$ century in continental Europe. Its basic principles stem from an intersection between Roman law and $18^{\text {th }}$ century Natural Law. It found its clearest and most influential expression in the pertinent five articles of the French Code civil of 1804. However, this law of delict of the $19^{\text {th }}$ century, with its distinct focus on individuals and fault soon reached its limits when faced with the new technical, economic and social challenges of the industrialisation that began in England and then spread across continental Europe. Perhaps the most emblematic of these challenges were the increasing accidents in factories and coal mines. The modern law of delict was suddenly faced with new paradigms: enterprises (instead of individuals) as tortfeasors, technical risks (instead of misconduct) as the ground of liability, the spreading of loss through insurance instead of, or alongside, the shifting of loss through liability. The law of delict underwent manifold changes: ${ }^{1}$ within its framework, case law lead to modifications, and further development resulted in hybrid forms of "stricter" liability. Outside the civil code, the legislator reacted to newly emerging risks by introducing special no-fault-based liability rules on a case-by-case basis. These new forms of strict liability were often limited in scope and linked to liability insurance coverage. However, towards the end of the $19^{\text {th }}$ century, this modern era in the law of delict began to lose its shine. The law of delict of the German Civil Code $(B G B)$ of 1896 was the final chapter of this era. Numerous interventions during the late $19^{\text {th }}$ and the $20^{\text {th }}$ century have resulted in the loss of clear structures in the law of delict. Apparently unambiguous core dogmatic concepts and categories, such as unlawfulness (Rechtswidrigkeit) and fault, have become more ambiguous. However, jurisprudence and politics have not yet managed to reform the classic law of delict of $19^{\text {th }}$ century codifications,

* Revised version of a framework paper which formed the basis of two seminars on liability law held by the author at Waseda University, Tokyo, Japan, in February 2019. A previous draft of this paper was published in Japanese in Waseda Law Review 2019, 373-402 and 2020, 313332, in German in Archiv für die civilistische Praxis 219 (2019), 771-817. - I dedicate this revised English version, published in a law journal based in the Netherlands, to the memory of my colleague Hans Nieuwenhuis, Leiden, who passed away five years ago.

** Unless otherwise acknowledged, translations of German-language legal texts into English have been made by the author.

1 For a "classic" overview cf. E. von Caemmerer, 'Wandlungen des Deliktsrechts', in Festschrift zum hundertjährigen Bestehen des Deutschen Juristentages (Karlsruhe: C. F. Müller 196o, vol. II) $49^{-136 .}$ 
neither in France nor in Germany. ${ }^{2}$ Before we can tackle the challenges of the $4^{\text {th }}$ industrial revolution (digitalisation ["Industry 4.0"/artificial intelligence]), we need to achieve clarity about the ways things have developed. Thus, this contribution focuses on the disputed basic structure of the civil law of delict. Further important aspects of the general law of delict, such as damage/harm/ loss, proof, multiple tortfeasors, proportional liability, mass torts, liability for subsidiaries and suppliers, and many more, must remain outside the scope of this contribution.

This multifaceted process of change has by no means been limited to the main civilian legal systems in continental Europe, rather it has also been seen in those non-European countries that have adopted European civil law. Japan is the most prominent example, having completed its civil code in $1898 .^{3}$ (China is a special case. After the collapse of the Chinese empire, the Chinese Republic adopted Japanese-European civil law in 1911, but after 1949, in the communist People's Republic civil law largely lost its importance. It wasn't until the economic liberalisation towards the end of the last century that China changed its approach. After the start with 'General Principles of Civil Law' (1986), the Chinese finally embarked on the project of a completely new civil code. In 2010, the law of delict entered into force as Book vin of the code. ${ }^{4}$ )

2 After the turn of the $21^{\text {st }}$ century, reforms of the codified law of obligations occurred in both countries. Contrary to the original plans, however, the law of delict remained unrevised. Cf. for France: L'avant-projet Catala de réforme du droit des obligations et du droit de la prescription (Sous-Titre III - De la responsabilité civile: Arts. 1340-1386), 2005 [but see now: Ministère de la Justice, Projet de réforme de la responsabilité civile, March 2017] and for Germany: Bundesminister der Justiz (ed.), Gutachten und Vorschläge zur Überarbeitung des Schuldrechts (Cologne: Bundesanzeiger Verlag 1981, vol. II) 1591-1834. The same holds true for the Japanese Act on the reform of the law of obligations, passed in 2017. - Initiatives to amend the law of delict in Austria (cf. n. 174) and Switzerland (most recently "Obligationenrecht 2020" (Arts. 46-63): http://or2020.ch) also failed. Whether the chapter on civil liability in the extensive reform project of the Belgian Civil Code (http://justice.belgium.be/fr/bwcc) will be adopted by Parliament remains to be seen. For an overview of and comments about the reform drafts of the law of delict in Austria, France (avant-projet Catala 2005), Switzerland (avant-projet 1999), and Turkey cf. B. Winiger (ed.), La responsabilité civile de demain/Europäisches Haftungsrecht morgen (Geneva/Brussels: Schulthess/Bruylant 2008).

3 The same applies to Korea, which adopted Japanese law in the 2oth century under Japanese hegemony.

4 It contains 12 chapters with 92 articles. Cf., among others, H. Koziol/Zhu Yan, 'Background and Key Contents of the New Chinese Tort Liability Law', Journal of European Tort Law 1 (2010) 328; G. Brüggemeier, Modernising Civil Liability Law in Europe, China, Brazil and Russia (Cambridge: CUP 2013) 167-213; H. Jiang, 'Chinese Tort Law: Between Tradition and Transplants', in M. Bussani \& A. J. Sebok (eds.), Comparative Tort Law. Global Perspectives (Cheltenham: Elgar 2015) 385 . 
In the third part of this contribution, I will attempt to sketch the basic structures of a postmodern law of delict in a transnational context. It is necessary to outline such structures as they constitute the indispensable foundation for further developments in the $21^{\text {st }}$ century. This applies to the European as well as the non-European civil law of delict. ${ }^{5}$

\section{2 The Birth of Modern Law of Delict}

By "modern law of delict", this contribution means the law of delict of the civil law codifications of the nation states of continental Europe in the $19^{\text {th }}$ century. In spite of the varying national designs, there are many common features. The basic structure and basic categories are identical: conduct, damage, causation, unlawfulness and fault. This is no coincidence. All these codifications are based on Roman law and Enlightenment Natural Law (Grotius, Pufendorf, Wolff et al.). ${ }^{6}$ The modern law of delict's journey began with the famous Articles 1382-1386 of the French Code civil (1804) and ended with formalistic law of delict of the $B G B(1896) .^{7}$

\subsection{The Foundation: Roman Law (lex Aquilia)}

While the Ancient Greek understanding of delict/tort revolved around general philosophical considerations about "just behaviour", 8 by the beginning of the $3^{\text {rd }}$ century BC, with its lex Aquilia, Roman law had laid out, for the first time, the basic structure of a civil delict: damnum iniuria datum (d.i.d.): ${ }^{9}$ damage

5 Apart from East Asia, other areas where European civil law was received include Central and South America. Cf. M. de Morpurgo, 'Tort Law in Latin America', in Bussani \& Sebok (eds), Comparative Tort Law (n. 4) 474, and in general J. H. Merryman/D. S. Clark/J. O. Haley, The Civil Law Tradition: Europe, Latin America, and East Asia (Charlottesvilles: The Michie Comp. 1999).

6 Cf. in general F. Wieacker, Privatrechtsgeschichte der Neuzeit (Göttingen: Vandenhoeck \& Ruprecht, 2nd edn. 1967) 97-347; R. Zimmermann, The Law of Obligations. Roman Foundations of the Civilian Tradition (Cape Town: Juta 1990) - and on law of delict in particular: N. Jansen, Struktur des Haftungsrechts (Tübingen: Mohr Siebeck 2003) 271-360.

7 First came the Prussian Allgemeines Landrecht (General State Law) of 1794, followed by the French Code Civil (1804), then the Austrian General Civil Code (ABGB) of 1811, the Dutch Civil Code (BW) of 1838, the Swiss Code of Obligations (OR) of 1881 and the Spanish Civil Code of 1889. The Italian Codice civile of 1865 had literally adopted the law of delict of the French Civil Code. This did not change until the Codice civile was fundamentally amended in 1942.

8 Cf. J. Gordley, 'Tort Law in the Aristotelian Tradition', in D. G. Owen (ed.), Philosophical Foundations of Tort Law (Oxford: OUP 1995) 131.

9 Cf., among others, B. Winiger, La responsabilité aquilienne romaine. Damnum iniuria datum (Basel: Helbing Lichtenhahn 1997) with further references. 
caused to another through wrongful conduct. At first glance, we seem to have almost all the ingredients of a modern delict: conduct, damage, causation, and iniuria. However, a closer analysis reveals that the d.i.d. formula emerges as mere paraphrasing by Roman jurists of the few casuistically regulated delicts (killing, injury to slaves and four-legged animals; burning, breaking, and damaging objects) in the Aquilian Act. These delicts are, without exception, direct acts of intentional injury or damage. From today's perspective, fault is the only ingredient lacking in the di.d. paraphrase of the Aquilian delicts. This omission is sometimes interpreted in such a way that Roman law civil liability was originally no-fault liability, that the focus was not on the perpetrator, but on contempt for the legal order. In my opinion, this is only partly true. The focus was on the injurious act. These delicts are acts of direct injury or damage (killing, burning, breaking), typically done with intent. That intention is not mentioned in the lex Aquilia can be explained by the fact that in this early phase of Roman law there is not yet any conceptual differentiation between wilful behaviour (concept of action) and intent to injure (fault concept of intention). This supposed strict liability was in fact a typified liability for intentional delicts. ${ }^{10}$ An independent notion of fault had not yet evolved. In other words: the iniuria of the lex Aquilia must be classified as 'unlawful intention', as deliberate injury or damage without justification (volenti non fit iniuria).

This interpretation appears to be confirmed by further developments. It was not until the end of the $3^{\text {rd }}$ century BC that fault appeared as a legal category in the Roman law of delict, albeit only in the shape of negligence (culpa). Mucius had already defined culpa as the foreseeable and avoidable harming of another person, seen from the perspective of a vir diligens. ${ }^{11}$ This objective standard of a reasonable person has to this day determined the conception of negligence in civil law. Culpa was later differentiated into various degrees of fault. ${ }^{12}$ Thus negligence differs from intention (dolus) as a category of fault. However, in Roman law, the intentional wrong remained the dominant form of delict throughout, whereas acts of negligence and some cases of no-fault liability were considered to be quasi-delicts. Indirect injuries were also later included. For this purpose, analogue forms of legal actions - the actiones in factum - were

$10 \quad$ Similar M. Kaser/R. Knütel, Römisches Privatrecht (Munich: Beck 18th edn. 2005) 177 marginal note 6.

11 Digests [Watson's transl.], Book 9, Chapter 2, 31 (Mucius' tree cutting case): "there is fault when what could have been foreseen by a diligent man was not foreseen or when a warning was shouted too late for the danger to be avoided."

12 Gross negligence (culpa lata), ordinary negligence (culpa levis), and slight negligence (culpa levissima). 
introduced. (In the English common law, the action on the case had a similar function.)

The emergence of culpa raised the problem of how to integrate it into the existing structure of the Aquilian delicts as typified intentional acts. To this end, formulas were found, which facilitated the co-existence of the categories iniuria and culpa. As Ulpian put it: It is unlawful to harm somebody in a blameworthy fashion (i.e. through negligence). ${ }^{13}$ In other words: proof of culpa/negligence constitutes iniuria. Therefore, unlawfulness/iniuria is not an intrinsic prerequisite of a delict of negligence; instead the negligent way of injuring/causing loss is what constitutes the unlawfulness of the action. Apocryphal and debatable in detail as this may be, it seems to present us with the foundations of the two-tier structure of delict: intention and negligence, which also finds expression in the terminological differentiation between delictum and quasi-delictum. In any case, disputes over the conundrum of "unlawful damage" /"danno ingiusto" were to remain on the agenda of the European civil law of delict (and its legal transplants) to this day.

\subsection{Prominent Examples of Modern Law of Delict: The French and German Civil Codes}

\subsubsection{Articles 1382-1386 Code Civil 1804}

The French law of delict of Arts. $1382-1386^{14}$ is the most striking example of the combination of the long Roman legal tradition and the legacy of Natural Law. ${ }^{15}$ It is the law of delict of free and equal citizens, breaking away from the casuistry of the Roman law of delict and French provincial laws. This resulted in the formulation of one fundamental norm of fault-based liability. The individual can only be held responsible for damage if he/she abuses his/her freedom of action (faute personnelle). The authors of the Code civil do in fact revert to the traditional d.i.d.-formula of the lex Aquilia, but with a new contemporary

13 Ulpian, Digests 9, 2, 5.1: "[In the lex Aquilia] therefore, we interpret iniuria for present purposes as including damage caused in a blameworthy fashion, even by one who did not intent the harm."

14 Since the reform of the law of obligations in 2016, the numbering of the articles has changed. Under the heading "La responsabilité extracontractuelle en général", Arts. 138286 turned into Arts. 1240-1244. The above text keeps the former numbering system to make it easier to comprehend for non-French readers. The new numbering system is only used in cases where the exact wording of the actual law in force is important.

15 Cf., inter alia, G. Viney/P. Jourdain/S. Carval, Traité de Droit Civil. Les conditions de la responsabilité (Paris, LGDJ $4^{\text {th }}$ edn. 2013), and as a comparative perspective of the actual law and the reform project 2017 (n. 2) see J. S. Borghetti/S. Whittaker (eds), French Civil Liability (Oxford: Hart 2019). 
emphasis: the central issue is now fault instead of iniuria: ${ }^{16} \mathrm{He} / \mathrm{she}$, who causes damage to another person through misconduct, is subject to liability (Art. 1382). ${ }^{17}$

This sentence is correct and incorrect at the same time because the wording of the Code civil does not contain such a general clause of fault liability. The drafters also seem to have followed the Roman law tradition in that respect as they introduced two separate heads of fault liability: dolus and culpa. In the fore, there is faute délictuelle in Art. 1382. As mentioned above, faute takes the place of iniuria in the Aquilian formula. Faute délictuelle means intentional fault and comprises - as in the lex Aquilia - of only deliberately caused harm (damnum dolo datum). Liability for negligence is treated separately (damnum culpa datum). It was subordinated to Art. $1383^{18}$ under the label - nowadays obsolete - of quasi-delict (faute quasi-délictuelle/négligence).

However, French jurisprudence and legal scholarship/doctrine (la doctrine) have de facto transcended this historically-determined legislative distinction. Today, both articles are treated as if they constituted a general clause of faultbased liability, i.e. liability of persons and other actors (enterprises, etc.) for intentional and negligent causation of damage. However, treating the provisions in this way glosses over the possible structural differences of both forms of fault-based liability, which was suggested by their separate regulation in two different provisions. The category of unlawfulness (illicéité) is nowhere to be found in the wording of the Code. It is used in academic writing, but its contours remain diffuse. Illicéité means breach of written and unwritten rules of

16 Likewise, § 1295 para 1 Austrian Civil Code. - In contrast, the Dutch Civil Code (BW) 1838 and the Swiss Code of Obligations (OR) 1881 adopted the Aquilian d.i.d. formula, but linked unlawfulness with fault: Art. 1401 Dutch Code (BW) 1838: "Every unlawful act which causes damage to another makes the person whose fault caused the damage liable to make compensation". Art. 50 OR 1881: "A person who unlawfully causes damage to another, be it through intent or through negligence, is obliged to compensate." This connection between unlawfulness and fault also dominated the law of delict of the BG B of 1896 (cf. further down in the text). Interestingly, the Spanish Code of 1889 returned to the French (and Austrian) approach and did without unlawfulness (Art. 1902). - The new Italian Codice civile of 1942 focused on the intentional or negligent causation of a "danno ingiusto" (Art. 2043).

17 „Tout fait quelconque de l'homme, qui cause à autrui un dommage, oblige celui par la faute duquel il est arrivé à le réparer." (unchanged, now Art. 1240)

18 "Chacun est responsable du dommage qu'il a causé, non seulement par son fait, mais encore par sa negligence ou par son imprudence (now Art. 1241, unaltered). Likewise Art. 1402 Dutch BW of 1838 . 
due behaviour. ${ }^{19}$ In French law, both categories, faute and illicéité, are closely interwoven, if not synonymous.

A further characteristic of the French law of delict is the unspecified notion of damage - dommage. In principle, it covers everything: personal injury, property damage, pecuniary loss, non-pecuniary loss, ecological damage. This was probably a consequence of adopting the paraphrase of the delicts of the lex Aquilia (damnum iniuria datum) without their casuistic foundation. Corrections had to be found via causation or fault.

Apart from liability for one's own wrongful conduct (fait personnel), Arts. 1382-1386 merely contain two further classic delicts of Roman law origin: liability for damage caused by third parties (fait d'autrui/vicarious liability) and responsibility of owners of things (fait des choses): animals and buildings. This will be further elaborated later in the text.

\subsection{2 $§ \S 823-85^{2}$ Bürgerliches Gesetzbuch 1896}

The German $B G B$ was the last grand codification of $19^{\text {th }}$ century Europe. This also explains why its specific form has been influenced not only by Roman law and Enlightenment Natural Law scholarship, ${ }^{20}$ but also by a historically evolved, highly developed systematic jurisprudence that had flourished during the latter half of the nineteenth century. This resulted in some formalism, perfectionism, and a focus on detail, all of which feature to some degree in the sections on the law of delict. The law of delict of the $в G B$ contains six times as many provisions as its French equivalent. It is characterised by three heads: general fault-based liability ( $\$ 823$ para 1), culpable breach of a statutory duty ( 8823 para 2), and liability for intentional causation of damage contrary to public policy (good morals) as per $\S 826$. Also, of particular importance is the rule on vicarious liability $(\S 831)$. In this section I will restrict myself to the main provision of $\S 823$ para 1:

One who, intentionally or negligently, unlawfully injures the life, body, health, freedom, property or other right of another, has an obligation to the injured party to compensate the resulting damage.

19 Illicéité understood as 'une contravention à un devoir de bon comportement'. See also Avant-projet Catala (n. 2), Art. 1340: „Tout fait illicite ou anormal ayant causé un dommage à autrui oblige celui à qui il est imputable à le réparer." In contrast, the Projet de réforme 2017 (n. 2) mentions illicéité only in Art. 1266 (cessation de l'illicéité).

20 Cf. Jansen, Struktur des Haftungsrechts (n. 6), 271-360; W. Ernst, 'Negligence in 19th Century Germany', in E. J. H. Schrage (ed.), Negligence. The Comparative Legal History of the Law of Torts (Berlin: Duncker \& Humblot 2001) 341 with further references. 
The law of delict of the $B G B$ shares the pathos of the philosophy of the Enlightenment and Natural Law: it is fault, not the damage caused, which obliges compensation. ${ }^{21}$ The individual is liable only for his/her personal wrongful conduct. This is where the common ground with French law of delict ends, however. The rest is a late reconstruction of Roman law in terms of a rigid legal terminology and norms theory. $\S 823$ para 1 is characterised by the dichotomy of grounds of liability (Haftungsgrund) and consequences/assessment of liability (Haftungsausfüllung), with the grounds of liability structured in three tiers: objective elements, unlawfulness, and fault.

The fleshing out of objective elements (Tatbestand) is a new version of damnum datum. To a certain extent, this is a return to the basic casuistry of the lex Aquilia, before the paraphrasing of its delicts through the Aquilian d.i.d.formula: It is not the causing of damage which triggers liability, but the injury of protected legal interests (life, body, health, freedom) - as differentiated in natural law - and the infringement of property-like absolute rights. This might also be understood as a reaction to the widespread criticism of the blanket approach of the French law of delict. Thus, the objective elements consist of three categories: conduct (action or omission), injury (of a right or protected interest), and causation.

Next in line are the two categories of unlawfulness and fault. Their relationship proved to be an awkward problem for all codifications of the law of delict. The drafters of the $B G B$ acted on the basis of the Natural Law doctrine of Erfolgsunrecht, ${ }^{22}$ according to which any direct injury of a protected interest leads to a presumption of unlawfulness. This does not apply if the injurious act was in some way justified (self-defence, consent, etc.).

In the case of an objective and unlawful injury, the third feature comes up: fault with its subcategories intention and negligence. Unlike in the delicts of the Aquilian and French law, but similar to the Swiss model of 1881, intention and negligence are explicitly mentioned and treated on par in $\S 823$ para. 1. Noteworthy is the classic definition of negligent fault:

21 A well-known phrase by R. von Jhering. Cf. idem, Das Schuldmoment im römischen Privatrecht (Giessen: Roth 1867) 40. Cf. also the explanatory materials in the First Draft of the law of delict of the BG В (von Kübel, Teilentwurf Unerlaubte Handlungen, 1880-82), published by W. Schubert (ed.), Die Vorlagen der Redaktoren für die Erste Kommission, Schuldrecht 1 (Berlin: de Gruyter 1980) 653, 660-664.

22 Especially on Grotius and Wolff, cf. Jansen, Struktur des Haftungsrechts (n. 6), 328 ff., 349 ff. and id. (ed), The Development and Making of Legal Doctrine (Cambridge: CUP 2010). 
Negligent conduct means not taking due care in the given circumstances. ${ }^{23}$

Provided these grounds of liability are met, the question of the assessment of liability is raised. ${ }^{24}$ The injury must have caused financial loss (primary loss and consequential losses). Pure economic losses are not covered by $\S 823$ para $1,{ }^{25}$ non-pecuniary loss (e.g. compensation for pain and suffering) was only exceptionally recoverable.

It will have become evident by now that the comparatively late law of delict of the $B G B$ aims at clarity of terms and structure. Thus, the concept of action (wilful conduct) and the concept of fault (intention: deliberate and conscious injury/negligence: blameworthy injury) are strictly separated in practice and doctrine. On the other hand - probably influenced by Roman law and German penal law (the latter was codified in 1871) - the concept of the intentional act heavily influenced the structure of the $B G B$ law of delict. However, it is highly doubtful whether, in civil law, intentional and negligent delicts are identical in structural terms. The intensive discussions during the second half of the $20^{\text {th }}$ century in German jurisprudence about Erfolgsunrecht and Verhaltensunrecht were a dispute about the structural differences between intentional and negligent delicts rather than about a generally valid definition of unlawfulness. ${ }^{26}$ The doctrine of Erfolgsunrecht applies to intentional delicts, that of Verhaltensunrecht to negligent delicts. As Ulpian had already realised: in delicts of negligence, the negligent manner of the injurious conduct constitutes the iniurial Rechtswidrigkeit/wrongfulness. ${ }^{27}$ This point will be taken up again in the third chapter.

$23 \S 276$ para 2: "Fahrlässig handelt, wer die im Verkehr erforderliche Sorgfalt außer Acht lässt".

24 As mentioned at the beginning, the assessment of liability with its elements of damage/ loss and causation of damage (by the injury of a protected interest) cannot be further considered in this paper.

25 If applicable, this is compensable under $\S 823$ para. 2 : culpable breach of statutory duty or under $\S 826$ : intentional causation of loss contrary to public policy.

26 To safeguard the three-tier system of delict's structure in negligence cases, different steps have been taken: "proper conduct" (verkehrsrichtiges Verhalten) was introduced as reason of justification (Bundesgerichtshof, 4.3.1957, BG HZ 24, 21), a controversial splitting of negligence into "external" and "internal care" was discussed (cf. E. Deutsch, Allgemeines Haftungsrecht (Cologne: Heymanns, $2^{\text {nd }}$ edn. 1996) 248 ff.), and a differentiation between direct and indirect injuries was applied (E. v. Caemmerer, 'Wandlungen des Deliktsrechts' (n. 1), 48, 71 ff.).

27 On the relationship between unlawfulness and wrongfulness, see infra the text (4.1.2.1). 
It was not surprising that in the ensuing period the catalogue of enumerated, protected interests in $\S 823$ para 1 turned out to be too restrictive. In particular, from 1949 onwards, the constitutionally-required protection of personality rights led to serious disruptions in the law of delict of the $B G B$. Work on the $B G B$ of 1896 was, in itself, an expression of the dilemma of modernisation: the liberal codification could not keep pace with the speed of economic development and social change in the late German Empire. As far as the $B G B$ law of delict was concerned, the focus on individual fault - even in employers' vicarious liability ( $(831)$ - was far from satisfactory. Unlike France in the year 1804, Germany, at the end of the $19^{\text {th }}$ century, was already one of the most developed industrialised countries, and the problems and risks entailed in this development could not be ignored. To the extent that they were even noticed, the common attitude was that these problems should be regulated by special legislation outside of the $B G B{ }^{28}$

\subsection{Legal Transplant: Arts. 709-724Japanese Civil Code $1898^{29}$}

In Japan, work on a modern legal system started after the opening-up of the country in 1868. It was dominated by European influences. Up to 1890, the main focus was on French law, afterwards on German law. At first glance, the basic norm, Art. 709 of the Japanese Civil Code (JCC) from 1898, comes very close to Art. 823 para $1 B G B$ :

A person who has intentionally or negligently infringed any right of others shall be liable to compensate any damages resulting in consequence. ${ }^{30}$

Common to both is the separation of grounds and assessment of liability, the focus on infringement of a right, and the equivelant status of intention and negligence as forms of fault. What is striking is the absence of the category of unlawfulness, in contrast to German (or Dutch (1938) and Swiss (1881)) law. The protected "right" is not only understood as an absolute subjective right in terms of property, patents etc., but also includes such legal interests as life, bodily

28 In the final phase of deliberations on the law of delict, there were unsuccessful attempts to incorporate Gefährdungshaftung for industrial risks and a rule of general enterprise liability, existing in special legislation (cf. notes 38,83 ), into the BGв law of delict. Cf. L. Lenz, Haftung ohne Verschulden in deutscher Gesetzgebung und Rechtswissenschaft des 19. Jahrhunderts (Münster: LIT 1995) $268 \mathrm{ff}$.

29 My main source is K. Yamamoto, Grundzüge des japanischen Schadensersatzrechts (Vienna: Sramek 2018); see also E. Matsumoto, 'Tort Law in Japan', in Bussani/Sebok (eds), Comparative Tort Law (n. 4), 359 .

Translation is taken from Matsumoto, 'Tort Law in Japan' (n. 29), 359, at 363. 
integrity, freedom, honour, as well as wealth (Vermögen). In spite of this relatively broad interpretation of the term "right", the economic and social developments of the $20^{\text {th }}$ century nonetheless resulted in problems extending liability. To enable this extension beyond the "infringement of any right" legal practice and jurisprudence reverted to the category of unlawfulness, prominently applied in the German law of delict. The concordance was, however, limited to the use of this term. In the traditional $B G B$ law of delict, unlawfulness resulted from an objective infringement of a protected interest, whereas in Japanese law, it constituted an alternative ground of liability. A further area of application of this concept of unlawfulness was - just as in French law indirect torts of negligence. Because of this jurisprudential development, the term 'unlawful' was incorporated in the wording of Art. 1 para. 1 of the State Liability Act of $1947 .^{31}$ In the civil code's law of delict, on the other hand, the appropriate extension of the scope of application of Art. 709 was to be safeguarded through the addition of the formula "legally protected interests of others" as follows:

A person who has intentionally or negligently infringed any right of others, or legally protected interest of others, shall be liable to compensate any damages resulting in consequence. ${ }^{32}$

The vicarious liability of the employer requires a delict of the worker/employee. Formally, the employer can be exonerated (Art. 715). This option is, however, not used. Of particular note is the early inclusion of bereavement damages in wrongful death cases (Art. 711). ${ }^{33}$ The further development of this compensation to include a lumpsum payment for loss of earnings of the deceased is a noteworthy particularity of Japanese law.

However, the basic elements of a civil delict are not undisputed in Japanese doctrine and legal practice. The Japanese legal culture has not escaped the European controversies about the conundrum of "iniuria" (When is the harming

31 Law No. 125 of 1947, Art. 1 para. 1: "When a civil servant, authorized to exercise public authority of the state or of a public-law body, unlawfully causes damage to another person in the execution of his function, be it through negligence or intention, the State or the public body is liable for its compensation." (Transl. by the author from the German Yamamoto-Text)

32 Translation taken from Matsumoto, 'Tort Law in Japan' (n. 29), 359, at 382.

33 Applicable in English law since the Fatal Accidents Act of 1976; in Germany as late as 2017 through the Hinterbliebenengeldgesetz (Act on Compensation of the Bereaved): $§ 844$ para. 3 BGB. 
of another wrongful?) and the discussion is further complicated by some imprecision in the way legal categories are set out. ${ }^{34}$

\section{Crisis of Modern Law of Delict}

The various waves of industrialisation - steam engine, coal and steel industry, chemical industry and electrical engineering - were accompanied by an upheaval of working and living conditions for the people in the respective countries. Train, steamship, automobile and later aeroplane revolutionised mobility and transport systems. Alongside motorisation came the triumphant advance of the oil industry. These key words help us picture the socio-economic context. ${ }^{35}$ The main challenge for the $19^{\text {th }}$ century law of delict was twofold: finding ways to hold liable the new instigators of these developments - the enterprises, whether incorporated or not - and ensuring that liability law was able to account for the new technical risks. The search for solutions was increasingly influenced by another innovation of the late $19^{\text {th }}$ century - the spreading of losses through liability insurance. ${ }^{36}$ Enterprises could spread their costs in two ways: through private liability insurance and through surcharges for their goods and services. Another track of insurance coverage was public social security. ${ }^{37}$ Nowadays, in the event of personal injury, it is mostly the social insurance bodies (accident and health insurance) that act as refunding agencies who then, by means of subrogation, have recourse against the private party who is responsible (and covered by liability insurance). In a number of countries, social insurance solutions have completely supplanted liability law in selected areas (work accidents, medical accidents). However, consequential pecuniary loss (loss of earnings) and non-pecuniary loss (damages for pain and suffering) are not covered by these insurance schemes.

34 For example, the term fault liability also comprises strict liability.

35 For recent European comparative law accounts of the consequences for liability law, cf. M. Martin-Casals (ed.), The Development of Liability in Relation to Technological Change (Cambridge: CUP 2010) and W. Ernst (ed.), The Development of Traffic Liability (Cambridge: CUP 2010).

36 Cf. H. Kötz, Sozialer Wandel im Unfallrecht (Karlsruhe: C. F. Müller 1976); J. G. Fleming/ J. Hellner/E. von Hippel, Haftungsersetzung durch Versicherungsschutz (Frankfurt, Metzner 1980).

37 For a comparative European overview cf. U. Magnus (ed.), The Impact of Social Security Law on Tort Law (Vienna/New York, Springer 2003). 


\subsection{Enterprises as New Actors}

The field of enterprise liability is extremely complex. In the late $19^{\text {th }}$ century, enterprises were predominantly entities that mined coal and ore and produced manufactured goods. They were managed by natural persons - owners/ executives. The mining and production were carried out by workers. The raw materials and products were sold on the market to customers (traders or private consumers). Thus, for the law of delict, the field with its four actors was archetypically predetermined: enterprises, executives, workers, customers/ third persons.

\subsubsection{Industrial Accidents}

As far as the law of delict is concerned, the problem of industrial accidents in factories is located in the inner-organisational triangle of enterprise executive - worker. The death or invalidity of a worker amounts to social destitution for him (if he survives) and his family. The person-oriented law of delict could not have been expected to be of help. The idea of a fault-based liability of enterprises was beyond imagination. There was no direct delict of an identifiable person, the owner or the manager, and a norm which would have made the company liable for fault of the executives did not exist.

This scandalous social and legal policy, caused by the shortcomings of the law of delict, forced the legislator into action. After Germany's unification in 1871, a legislative provision entered into force, which made certain enterprises ("dangerous factories") liable for wrongful management decisions resulting in accidents at work. ${ }^{38}$ However, the workers affected and/or their surviving dependants had to prove the management's fault, which made this rule fairly ineffective. This was the only applicable law until Bismarck's social legislation in the 1880 s also laid down comprehensive new rules for "industrial accidents". Private law liability was supplanted by social insurance coverage (Act on Accident Insurance for Workers 1884). Premiums to this accident insurance had to be paid by the enterprises, which was an incentive for them to make progress in preventing injuries. ${ }^{39}$

Although the German path of social security remained rather unique, ${ }^{40}$ all Western industrial nations - whether under codified civil law or common law - were confronted with the failure of their law of delict/torts in the face of

$38 \S 2$ Reichshaftpflichtgesetz/Imperial Liability Act 1871 (today $\S 3$ Haftpflichtgesetz/ Liability Act).

39 Since 1925, social security schemes have also included work-related health damage ("work-related disease"). This would also comprise, e.g., asbestos-related illnesses, which are a disputed subject in many countries. 
such cases. In the USA, the deficits of traditional tort law were even regarded as deliberate subsidisation of the industrialisation process in the Northeast of the country. ${ }^{41}$ Eventually many countries took the path of strict regulation of liability for industrial accidents through the operation of special statutes outside of the civil code or common law of torts: in France, through the adoption of Loi du 9 avril in 1898, in Great Britain with the Workmen's Compensation Act of 1897. In the USA, it was not until 1910 that individual States started to introduce appropriate regulations, the Workers' Compensation Statutes. ${ }^{42}$

\subsubsection{Delicts/Torts of Employees / Vicarious Liability}

Under employer's vicarious liability, a third group - apart from the internal scenario of enterprises, managers, and employees - came into play: injured third parties. Without much ado, this variant of enterprise liability could attach itself to a traditional principle of Roman law of delict: "noxal liability for wrongs of third persons" (actio noxalis). Apart from liability of parents for their minor children and of supervisors for persons under their supervision, this also included liability of craftsmen for their assistants (master/ servant). The latter roles could now be assumed by entrepreneurs and workers, employers and employees. This legal principle of "liability for others" connects fault-based liability with strict, objective liability. The employee must have committed a classic delict "on the job". In this case, the employer, i.e. the enterprise for which he or she carried out the work, is liable for the damage caused. This results in a kind of strict liability of enterprises; at least in the strict variant of employer's liability which is a characteristic of the common law's vicarious liability. ${ }^{43}$ This also applies to Scandinavian law and most Romanic laws. In the French law of delict, following the Roman model, reference was still made to fault (Art. 1384 paras 3 and 5 C.civ. 1804). ${ }^{44}$ However, the jurisprudence soon oriented itself towards the strict liability of the principal. ${ }^{45}$ With the editorial

41 M. J. Horwitz, The Transformation of American Law 1780-1860 (Cambridge: Harvard UP 1977) 63-108; but see also G. T. Schwartz, 'Tort Law and the Economy in $18^{\text {th }}$ Century America. A Reinterpretation', Yale Law Journal go (1981) 1717.

42 The Federal Government led the way with the Federal Employers' Liability Act (FELA) for the interstate railways in 1908 .

43 For a recent comparative law contribution see P. Giliker, Vicarious Liability in Tort (Cambridge: CUP 2010); see also W. Swain, 'A Historical Examination of Vicarious Liability', Cambridge L. J. 78 (2019), 640. On employers' vicarious liability cf. D. Brodie, Enterprise Liability and the Common Law (Cambridge: CUP 2010).

44 Liability only applied if the principals "ne prouvent qu'ils n'ont pu empêcher le fait qui donne lieu à cette responsabilité" (Art. 1384 para 5 C. civ. 1804). The corresponding new Art. 1242 para 7 explicitly excludes the principals ("maitres et commettants").

Cf. Viney/Jourdain/Carval, Les conditions de la responsabilité (n. 15), 1077. 
revision in connection with the reform of the law of obligations in 2016, this was confirmed in the new Art. 1242. Japanese law has taken a similar path with $\S 715 \mathrm{JZG}^{46}$

The legal position is noticeably different in the Germanic laws. ${ }^{47}$ The German law of delict with its $\S 831$ BGB is a representative, even notorious, case in point. The flawed construction of this provision can only be explained against the background of the three-tier structure of the delict in $\S 823$ para 1 вG ${ }^{48} \S 831$ links the behaviour of two actors - employee and employer - in one delict. The starting point is the damage to a third party unlawfully caused by the employee "in execution of his/her employment." In this employee's delict, the third tier - fault of the employee - has been dropped. It was replaced by the employer's fault. ${ }^{49} \mathrm{As}$ a result, under $\S 831$, the employer is only liable for his own fault with regard to selection and supervision ${ }^{50}$ of the offending employee. The only concession made to the injured third parties consisted in the presumption of employer's fault in a case of employee's delict. It was this legal provision - which to this day has not been corrected ${ }^{51}$ - which induced German courts to relocate cases of delict to contract law and quasi-contract law (contracts with protective effect for third parties/culpa in contrahendo).

In the tradition of the person-oriented law of delict, employer and employee were always regarded as individuals, according to the model of master and servant. To this day, although it happens in practice, there is no statutory foundation for the attribution of managers' fault to incorporated industrial enterprises. ${ }^{52}$ Employer's liability as per $\S 31 \mathrm{BGB}$ - being merely a corporate variant of directors' personal delicts - does not solve the problem either. The personoriented law of delict thus draws a conclusion from the recognition of legal

46 See Yamamoto, Grundzüge des japanischen Schadensersatzrechts (n. 29), marginal note $653 \mathrm{ff}$. - On the new Chinese law cf. C. Ding, 'Development of Employer's Vicarious Liability', Journal of European Tort Law 5 (2014) 67.

47 Cf., apart from $\S 831$ B G B, in particular $§ \S 1314$, 1315 Austrian Civil Code and Art. 55 Swiss Code of Obligations.

48 Cf. above in the text (2.2.2).

49 On the issue that $\S 831$, contrary to its wording, also requires a fault of the employee, cf. already E. v. Caemmerer, 'Wandlungen des Deliktsrechts' (n. 1), 49, $124 \mathrm{ff}$. with further references.

5o Culpa in eligendo et instruendo in $\S 831$ B G B was extended early on breach of supervisory obligations (culpa in custodiendo). Reichsgericht, 14.12.1911, RGZ 78, 107; 25.2.1915, RGZ 87, 1.

51 On the contrary, it was even extended by the judicial recognition of a so-called decentralised proof of exoneration: Reichsgericht, 14.12.1911, RGZ 78, 107; Bundesgerichtshof, 25.10.1951, BGHZ 4, 1.

$5^{2}$ This problem does not arise in French, Scandinavian and Anglo-American principal's liability without the condition of principal's fault. 
persons. The legal person is not capable of action and fault. The law of delict has taken over this doctrine from criminal law. Incorporated enterprises act through the members of their executive body - directors and officers. If a member of the executive body within the scope of his/her responsibilities, commits a delict, whether intentionally or negligently, this is also classified as a delict of the legal person itself. Joint and several liability automatically applies to both, incorporated enterprise and acting director or officer. ${ }^{53}$

As for employer's vicarious liability, it is not clear whether this leads to joint and several liability of employer and employee. In principle, both can be liable - the offending employee and employer. In practice, however, what matters most is the "deep pocket". In cases of grave misconduct (gross negligence or intention) of the employee, the employer has a right of recourse. Nevertheless, the question of external liability of the employee - e.g. in case of bankruptcy of the employer's enterprise or lack of liability insurance - is in dispute. This issue is treated in very different ways by the national legal orders. In France, it has been negated, ${ }^{54}$ in England it is hardly applied at all. In Germany, external liability is affirmed in cases of direct injuries; in cases of indirect delicts - employees' fault during repair, production, construction, etc. - the legal situation is ambiguous. ${ }^{55}$ German law explicitly excludes liability of servants/employees only in cases of officials exercising public authority (Art. 34 Grundgesetz).

\subsubsection{Fault of Enterprises}

In hindsight, by far the most important development in the modern law of delict occurred almost by stealth in the transition towards a de-personalised, fault-based enterprise liability. It was brought about after the turn of the $20^{\text {th }}$ century through case law that effectively reduced the field of the law of delict to two actors. Employees and their delicts were no longer in focus, nor were the executives and their requirement of fault in the selection, supervision, and management of their employees. The focus was now on the enterprises in which work processes took place or through which services were provided,

53 On French law (responsabilité de la personne morale pour le fait de ses organs dirigeants) cf. Viney/Jourdain/Carval, Les conditions de la responsabilité (n. 15), $1141 \mathrm{ff}$. See also Projet de réforme 2017 (n. 4), Art. 1242-1.

54 Cf. Cour de cassation plén., 25.2.2000, Dalloz 2000, 673; Revue Trimestrielle de Droit civil 2000, 582 - Costedoat.

55 This is connected with the question - disputed in German law - whether the so-called duties of care (Verkehrspflichten) only apply to the self-employed (Bundesgerichtshof, Neue Juristische Wochenschrift 1987, 2510) or also include employed workers (Bundesgerichtshof, 19.11.1911, BGHZ 116, 104). Cf. G. Brüggemeier, Haftungsrecht. Prinzipien, Struktur, Schutzbereich (Heidelberg: Springer 2006) $151 \mathrm{ff}$. 
etc. - and the injured third parties. The third characteristic of this new type of liability was the lack of directness between action and injury. The focus is on remote damages. Causation between activity and injury/damage remained a necessary, but no longer sufficient, prerequisite of liability. As a further criterion for damages, attribution was required. This originally found expression, particularly in the Germanic laws, in the doctrine of adequacy (Adäquanz). But this category was soon replaced - following the example of Anglo-American common law of torts - by the vague concept of duty of care. ${ }^{56}$ In spite of numerous misunderstandings, this "duty" of care has nothing to do with either enforceable juristic obligations nor with standards of due care. It is merely a legal façon de parler. It determined, based on the causation given, the personal, spatial and temporal protective scope of liability. To have made this clear for the area of negligence liability is the lasting merit of Cardozo J's majority vote in the Palsgraf decision of the New York Court of Appeals in 1928, ${ }^{57}$ likely the most famous judgment in the US law of torts (Palsgraf Doctrine).

The predecessor and enduring prototype of this development towards enterprise liability for negligence, which was no longer based on the preceding individual fault of an employee or director/officer, is the non-contractual producers' liability. In Germany, a seminal decision of the Reichsgericht, delivered as early as 1915, is quite clear in its wording: there is a factual basis for liability of the enterprise "if it has been determined that the cause for the injury to the plaintiff originated in the factory of the defendant."58 It was then the burden of the enterprise to exonerate itself from blame. This was the birth of liability of enterprises for third-party damage caused by their activities, with the burden of proof regarding its unavoidability resting on the side of the enterprise. ${ }^{59} \mathrm{It}$

${ }_{5} 6$ Cf. C. von Bar, Verkehrspflichten. Richterliche Gefahrsteuerungsgebote im deutschen Deliktsrecht (Cologne: Heymanns 1980).

57 Palsgraf v. Long Island Railroad, 162 N. E. 99 (N. Y. 1928); on the facts of the case cf. further down in the text.

$5^{8}$ Reichsgericht, 25.2.1915, $R G Z$ 87, 1, 3: The female plaintiff bought medicinal salt in its original packaging from a pharmacy. The salt contained glass splinters, which, after consumption, caused damage to the woman's health. It could not be established how the splinters had found their way into the salt. For a later seminal judgment cf. Bundesgerichtshof, 26.11.1968, $B G H Z$ 51, 91 - fowl pest. - A simultaneous decision in the USA was MacPherson v. Buick Motor Co., 111 N. E. 1050 (NY 1916); however without reversal of proof for fault. Nevertheless, US law acknowledged prima facie evidence for enterprise negligence. Cf., inter alia, Escola v. Coca Cola Bottling Co., 150 P.2d 436 (Cal. 1944).

59 Similarly, see an early decision of the Privy Council: Grant v. Australian Knitting Mills Ltd. [1936] 1 AC 85 (PC); for Italy: Corte di Cassazione, 25.5.1964, Foro Italiano 1965, I, 2098 - Saiwa; for the Netherlands: Hoge Raad, 2.2.1973, Nederlandse Jurisprudentie 1973, 315 - baby water bottle; for Switzerland: Bundesgericht, 9.10.1984, BGE 110 II 456 Schachtrahmen. 
has been extended to environmental liability ${ }^{60}$ and serves as a general principle of non-contractual enterprise liability. ${ }^{61}$

\subsubsection{Culpa and Enterprises}

Unavoidability meant, and still means, absence of negligence. However, what exactly does the it mean for an enterprise to be negligent? Here we are no longer dealing with a question of carelessness and imprudence in human behaviour, nor of individual acts. The focus is on activities. Enterprises, irrespective of their legal form, are organised and structured entities. Negligence thus turns into liability for organisational fault. Enterprises are obliged to organise and supervise their workflows in such a manner that injuries to third persons are avoided. Their actions are based on mathematical calculations. In other words: They are "masters of statistics and economics". ${ }^{62}$ What counts are categories of profit and loss. Thus, it stands to reason that there will be a reversion to economic considerations of cost-benefit in these case scenarios - and only in these cases - to determine enterprise negligence.

In US law, this was achieved with the Learned-Hand formula: ${ }^{63}$ Negligence [of enterprises] is "a function of three variables: ( 1$)$ the probability of an accident $(P) ;(2)$ the gravity of the resulting injury or loss $(L) ;(3)$ the burden of adequate precaution $(B)$ ". We talk of negligence if B is less than P multiplied by L. To put it in more straightforward terms: enterprise negligence applies in cases where foreseeable damage could have been avoided by less costly precautionary measures. But there is no such thing as absolute safety. If the concrete damage only could have been avoided at higher costs, this is not a case of enterprise negligence. Here, for compensation to follow, further conditions beyond fault-based liability of the law of delict/tort must be fulfilled, no matter how quasi-strict this may present itself these days.

On the one hand, the Learned Hand formula aims at a better transparency in fixing the standard of due care, and in this respect was an antidote to the common practice which was pejoratively described as the "negligence

6o Bundesgerichtshof, 18.9.1984, $B G H Z$ 92, 143 .

61 Cf. further on in the text.

62 Cf. Holmes, The Path of the Law, 1897 (Reprint Harvard Law Review 110 (1997) 991, 1001): "For the rational study of the law the black-letter man may be the man of the present, but the man of the future is the man of statistics and the master of economics."

63 This is chiefly based on the opinion of Federal Judge Learned Hand in the decision United States v. Carroll Towing Co., 159 F.2d 169 (2d Cir. 1947): In the port of New York, which was very busy during war times (1944), a tugboat was moored. There were no security personnel on board during the night. Due to ship movements in its vicinity, the tug broke loose and drifted onto the Hudson River. It collided with another ship, sprang a leak and sank. The loss of boat and cargo could have been avoided if pumps had been used in time. 
lottery". ${ }^{64}$ On the other hand, however, and this is more important, it reveals the peculiarities of negligence in enterprise activities. The Hand formula was at the centre of the tort ideas of the Law \& Economics Movement on negligence, ${ }^{65}$ but could not assert its claim to universal applicability. In the end it still comes down to the discretion of the courts to establish which safety measures are required and can reasonably be expected of an enterprise and thus to determine the normative "standard of due care". This can be done by considering foreseeability, cost-benefit calculations and further criteria.

\subsubsection{Emergence of the Common Law Tort of Negligence}

The growing influence of the US and English law of torts on the codified laws of delict in Europe and Japan and on negligence liability does raise to a number of concerns. For a long time, the English common law of torts was characterised by a number of typified groups of intentional direct infringements: trespass to the person (battery, assault etc.), trespass to goods, trespass to land. Trespass on the case (later: action on the case), comparable to the Roman law actio in factum, was successively introduced as a form of action for omissions and indirectly damaging actions. In the $19^{\text {th }}$ century, this developed into the separate tort of negligence. ${ }^{66}$ Eventually this new tort also covered, apart from omission and indirect injuries, direct non-intentional acts of infringement. ${ }^{67}$ Common lawyers looked for an idea which would justify this extension of liability and restriction of freedom of action. In combination with the influence of Natural Law doctrines of human duties of behaviour, this resulted in the concept of a "duty to take reasonable care not to injure one's neighbour." 68 Hence, negligence, which in the course of the $19^{\text {th }}$ century developed into the dominant tort in the common law family, consists of four basic elements:

Duty of care, breach of duty (fault), injury/damage/loss, and causation.

64 Cf. M. A. Franklin, 'Replacing the Negligence Lottery', Virginia L. Rev. 53 (1967) 774; P. S. Atiyah, The Damages Lottery (Hart: Oxford 1997).

65 Fundamental on this issue R. Posner, 'A Theory of Negligence', Journal Legal Studies $1(1972) 29$.

66 Cf., e.g., D. J. Ibbetson, 'The Tort of Negligence in the Common Law in the Nineteenth and Twentieth Centuries', in Schrage (ed.), Negligence (n. 20), 229.

67 In this respect, Brown v. Kendall, 6o Mass 292 (1850), is fundamental for American Common Law.

68 F. Buller, An Introduction to the Law of Trials at Nisi Prius (London: Woodfall \& Strahan 1767) 35-36. The "neighbour principle" developed into a decisive factor in the English tort law of negligence. For criticism of this development, see, amongst others, W. W. Buckland, 'The Duty to Take Care', Law Quarterly Review 51 (1935) 637. 
Another consequence of this development and the varying legal history of civil law and common law is a fundamental difference in the understanding of a wrong (delict/tort). In the civilian tradition, a delict is a wrongful injury (damnum iniuria datum). Whereas in common law, a wrong/tort is generally conceived as breach of a legal duty. ${ }^{69}$

\subsubsection{Three Variants of the Negligence Delict}

From a civil law perspective, various types of negligence delicts must be extracted from this uniform structure. (i) The direct injury of protected interests through negligent human conduct (positive act). An example is the conduct of the railway company employees in the Palsgraf case who, through carelessness, had caused the fall of the parcel. ${ }^{70}$ This first type mainly covers accident situations - from traffic and sports accidents to medical accidents (e.g. the doctor performing a surgery and accidentally severing a patient's nerve or operating on the wrong leg). In these cases, as in cases of intentional injuries, an additional duty not to damage is not required. Since the lex Aquilia, this wrongful conduct has been sanctioned by the law of delict, without recourse to a juristic or moral "duty of care". (ii) Omissions are a separate category. They require an affirmative duty to act: Whoever creates a source of danger is responsible for arranging the relevant protective measures to make it safe. Certain groups of people are under such duties to act because of their profession doctors, police, pool attendants - which does not apply to others. ${ }^{71}$ Negligence is merely concerned with the question whether the measures, which were due but not taken, remained avoidably undone. However, this affirmative duty to act has nothing to do with a duty of care. In this respect, e.g., the German law differentiates between affirmative duties to procure safe spaces (Verkehrssicherungspflichten) and duties of care (Verkehrspflichten). Finally, there are (iii) negligently caused remote harms. ${ }^{72}$ Duty of care falls under this

69 Cf. P. Birks, 'The Concept of a Civil Wrong', in Owen (ed.), Philosophical Foundations (n. 8) with further references. - In some recent reform drafts of the law of delict in Europe, this common law concept of breach of duty of care is invading in the civil law and ousting its traditional approach. Cf. e.g. the Swiss "Obligationenrecht 2020" (n. 2), Art. 46: delict as an "infringement of a duty of care without justification".

$70 \quad$ Cf. n. 57.

71 For German law, see especially Bundesgerichtshof, 23.11.2017, $B G H Z$ 217, $5^{0}$ - swimming baths.

72 Remote damages are divided into two basic types: (1) remote initial damage, and (2) direct (primary) damage to one victim and indirect secondary damage to another victim. An example for (1) is manufacturers' liability, examples for (2) are, inter alia, cases of damage caused by nervous shock. Cf. further down in the text. 
category. ${ }^{73}$ It determines the personal, spatial and temporal scope of liability, which in turn results in problems of distinction from the criterion of proximity/proximate cause. When understood as instrument to determine the scope of protection (Palsgraf doctrine), the doctrinal device of duty of care is identical to that of proximity.

In the category of negligent remote damage, there are two types of protagonists: natural persons and enterprises. As far as the actors are identifiable natural persons, these are usually cases of vicarious liability. This attribution of a remote injury to the conduct of employees was at the centre of the Palsgraf case and the Australian Wagon Mound cases. ${ }^{74}$ Here negligence is determined according to the classic criteria (vir dilligens). Whenever enterprises are involved, which is the case in most instances of producer and environmental liability, the above principles of depersonalised negligence or liability for organisational fault apply (with or without reversal of burden of proof). Approaches such as the Learned Hand Formula only cover these latter cases of enterprise negligence.

Causation is a prerequisite in all these various types. But the question remains: causation of what? An independent concept of action has not been developed for the common law tort of negligence. Behaviour or activity and fault or negligence continue to form a pre-modern conceptual unit. Unlawfulness, on the other hand, is rightly not mentioned at all. In this respect, the negligence liability of common law (and the French law of delict) is a model for the European civil laws of delict. This will be further explored in part C.

\subsection{Challenge of New Technical Risks}

Production techniques in the factories were determined by the iron and steel industry and mechanical engineering. Electrical engineering and chemical industry were gaining ground. Railway and steamship revolutionised the transport sector and were soon joined by automobile and aeroplane. Whereas the reaction to industrial accidents had been similar, albeit not simultaneous, outside of the law of delict, ${ }^{75}$ there were vast differences amongst the national answers to the challenge of the new technical risks. Three representative forms of response can be found: (1) the French path: judge-made general clause of

73 Alternatively, categories of normative causation are applied: proximate cause or legal cause. Cf. T. Honoré, 'Causation and the Remoteness of Damage', Intern'l Encyclopedia of Comp. Law (The Hague: Kluwer Law Intern'l 1971, vol. XI) ch. 7 .

74 Overseas Tankship (U.K.) Ltd. v. Mort's Dock \& Eng'g Co. (The Wagon Mound (No. 1)) [1961] A.C. 388 (P.C.); Overseas Tankship (U.K.) Ltd.v. The Miller Steamship Co. (The Wagon Mound (No. 2)) [1967] A.C. 617 (P.C.). On the facts of the case, see further down in the text. 
no-fault liability, (2) the German path: special statutes of Gefährdungshaftung, (3) the path of Common Law: retaining the negligence tort.

\subsubsection{The French Path: General Clause of No-Fault Liability}

The law of delict of the Code civil acknowledged three types of wrongs: personal fault, responsibility for delicts of third persons - and liability of keepers of animals and owners of buildings. It was obvious that this law of delict was not able to react appropriately to the manifold challenges of industrialisation, which led to intensive discussions and various conceptual proposals ("théorie du risque") about how this gap could be filled. ${ }^{76}$ The problem was solved through innovative case law. In 1896, the Cour de cassation finally managed to deliver a fundamental re-interpretation of Article 1384 para $1 .{ }^{77}$ Significantly, the famous Teffaine case concerned an accident at work. ${ }^{78}$ Until then, Art. 1384 para 1 had been understood as a mere transitory step towards the subsequent regulations of "liability for others" of parents, teachers and supervisors, employers, as well as of "liability for objects" (animals, buildings). Now the Cour de cassation interpreted this article as a genuine ground of no-fault liability for damage resulting from things under one's care or control. This was the birth of a general clause of no-fault liability for objects of any kind, whether hazardous or not. Shortly afterwards, work accidents were regulated by special rules, ${ }^{79}$ and apart from steamship and rail accidents, automobile accidents soon became one of the main areas of application. The two fundamental Jand'heur judgments brought the - long overdue - clarification that things "held in the hand and under human control" also resulted in liability under Art. 1384 para $1 .{ }^{80}$ If the guardien was an employee who used the object within the scope of his work, the employer was considered the solely responsible keeper in terms of Art. 1384 para $1 .^{81}$ It was not until 1985 that traffic accidents with automobiles were brought under a special regime through the Loi Badinter.

76 Cf. Bürger, Der Artikel 1384 Abs. 1 Code Civil und die Entwicklung der ,théorie du risque“ (Dissertation Würzburg 1964).

77 „On est responsable non seulement du dommage que l'on cause par son propre fait, mais encore de celui qui est causé par le fait des personnes dont on doit répondre, ou des choses que l'on a sous sa garde (unaltered now Art. 1242 para 1).

78 Cour de Cassation, 18.6.1896, Dalloz 1897, 1, 433; Sirey 1897, 1, 17: Explosion of a steam boiler on a barge.

79 Cf. above in the text.

8o Cour de Cassation civ., 21.2.1927, Dalloz, recueil périodique 1927, 1, 97; and Cassation, Chambres réunies, 13.2.1930, Dalloz, recueil périodique 1930, 1, 57.

81 Viney/Jourdain/Carval, Les conditions (n. 15), 684. 


\section{2 .2}

The German Path: Special Statutes of Gefährdungshaftung

The German path had a curious origin. As early as in the 1830 s, the attentive civil service of the Prussian State worked out a plan to embark on a comprehensive regulation for railroads, which were only just beginning to emerge. In 1838 , at the time the Act was passed, Prussia was dominated by agriculture and had hardly any railways at all. This Act included a liability rule (§ 25) which was later - and probably mistakenly - regarded as the beginning of Gefährdungshaftung. In 1871 , this no-fault liability of railway companies ${ }^{82}$ became, in a slightly modified form, the law in the entire newly-founded Empire. ${ }^{83}$ In Austria, a corresponding law was passed in 1869 . Russia adopted an Act regulating liability of railways and steamships in 1878 .

The breakthrough to Gefährdungshaftung, as it is understood today, came in 1909 with the regulation of car owners' liability in the Act on Traffic of Automobiles $(\S 7)$. All remaining references to fault liability were removed. The focus was on the operational risks of the vehicle. From the outset, insurability of this liability risk accomanied this new Gefährdungshaftung. From 1939 onwards, this symbiosis of Gefährdungshaftung for automobiles and liability insurance has been legally acknowledged by the transition to compulsory insurance following the Scandinavian model. - The next steps were legislation on aircraft liability (1922), power and gas supply facilities (1943), water and soil pollution (1957), atomic energy (1959), trams and cableways (1978), soil and air pollution by specific listed facilities (1990) and genetic engineering (1990).

These regulations, although very different in detail, all have in common that they require the existence of a specific technical risk. ${ }^{84}$ Unlike in product liability, they are concerned with typical risks, not with defective objects ${ }^{85}$ or poorly organised operating procedures. In Gefährdungshaftung, this risk context is the central element of liability and also defines the contours of liability. Its proprium is the acceptance of technical risks by society with the concurrent social pressure to tolerate these risks. ${ }^{86}$ With few exceptions, the scope of

82 Or liability for irrefutably presumed fault of the railway company. For these discussions on $§{ }_{25}$ Prussian Railway Act and § 1 Imperial Liability Act cf. R. Ogorek, Untersuchungen zur Entstehung der Gefährdungshaftung im 19. Jahrhundert (Frankfurt: Klostermann 1975); G. Brüggemeier, 'Gefährdungshaftung, Unternehmenshaftung, Verschuldenshaftung', in Festschrift H. Rüßmann (Saarbrücken: juris 2013) 265 with further references.

83 § I Imperial Liability Act 1871.

84 Cf. E. Deutsch, 'Methode und Konzept der Gefährdungshaftung', Versicherungsrecht $1971,1$.

85 In that respect, the so-called strict product liability is not Gefährdungshaftung in the above sense.

86 Cf. J. Esser, Grundlagen und Entwicklung der Gefährdungshaftung (Munich: Beck 1941) $92 \mathrm{ff}$. 
protection is limited to personal injuries and damage to property. Because these special regulations were distinct from the $B G B$ law of delict, it was not until the reform of damages law in 2002 that compensation for pain and suffering could be awarded under the rules of Gefährdungshaftung, although this law explicitly focused on personal injuries. ${ }^{87}$ Because of their importance beyond national borders, liability for plane accidents, accidents in sea transport and nuclear accidents became the subject of additional international agreements. $^{88}$

\subsubsection{The Path of Common Law: Tort of Negligence}

Casuistic common law, like Roman law, recognised a number of traditional forms of no-fault liability: trespass to land, conversion of property, liability for fire and wild animals. In the common law's tort jurisprudence, the new risks of industrial and technical developments were first addressed in a legendary English case from the 186os: Rylands v. Fletcher. However, its further development took place almost exclusively in US law.

Rylands v. Fletcher ${ }^{89}$ was a legal dispute between two industrialists. In an area dominated by mining, a textile manufacturer, Rylands, had a water reservoir built in the ground to supply his textile mill with water. The ground underneath was criss-crossed by mining galleries. The reservoir collapsed, and the escaping water flooded the galleries of Fletcher's mining company. Fletcher successfully sued for damages. While the lower courts had focused on the creation of a risk ("at his peril"), the House of Lords reverted to pre-modern strict liability and the infringement of neighbours' rights through "unnatural use of land".90

Though often cited in textbooks, this verdict had practically no impact in England. ${ }^{91}$ However, it was re-discovered in the USA after the turn of the $20^{\text {th }}$

87 Second Act amending the law of damages of 19.7.2002, Bundesgesetzblatt I 2002, 2674. By contrast, under animal owners' no-fault liability, which was regulated in $\S 833$ BG B, damages for pain and suffering could be awarded from the beginning.

88 Cf. further down in the text.

89 [1866] Law Reports 1 Ex. 265; [1868] Law Reports 3 H.L. 330.

9o P. 339: „One who uses his land unnaturally is liable for harm to his neighbour without fault." Cf., e.g., Simpson, 'Legal Liability for Bursting Reservoirs: The Historical Context of Rylands v. Fletcher', Journal of Legal Studies 13 (1984) 209.

91 In England, Rylands vs. Fletcher is nowadays treated as a case of private nuisance: F. H. Newark, 'The Boundaries of Nuisance', Law Quarterly Review 65 (1949) 480; Cambridge Waterv. Eastern Counties Leather plc [1994] AC 264 (HL); in Australia as negligence: Bournie Port Authority v. General Jones Pty Ltd. (1994) 179 CLR 520. For a critique of both cf. J. Murphy, 'The Merits of Rylands v. Fletcher', Oxford Journal of Legal Studies 24 (2004) 643. 
century. ${ }^{92}$ The legal renaissance had two phases. In the period after the civil war, in the industrial states of the North-East, strict liability for industrial risks was consistently seen as an obstacle to economic development. ${ }^{93}$ This attitude did not change until towards the end of the century, when the social consequences of unrestrained industrialisation could no longer be overlooked. Moreover, there were severe mining accidents and spectacular dam bursts. This put Rylands $v$. Fletcher back on the political agenda. The breakthrough came in 1930 with its recognition in the first Restatement of the Law of Torts. Sections 519, 520 stipulated strict liability for "ultrahazardous activities". With some modifications, this rule survived until the Third Restatement (Torts) in 2010 ("abnormally dangerous activities"). ${ }^{94}$

In summary, it must be noted, however, that technical means of transport from railways and steamships to automobiles and planes - have not been included to this day. The American understanding is that the development of safety technologies has rendered the introduction of strict liability superfluous. ${ }^{95}$ The handling of explosives is one of the few acknowledged cases of application. Liability for ultrahazardous activities has largely remained law in the books. ${ }^{96}$ In the USA, the only form of strict liability that remains relevant in practice - apart from the later special case of products liability - is the statutory Workers' Compensation regime outside of the common law. Remaining shortcomings of negligence liability in tort were in the end cured by legislative initiatives: with the Atomic Energy Act of 1954, the so-called Superfund of 1980 for environmental damages ${ }^{97}$ or the Oil Pollution Act of 1990.

92 Cf., inter alia, G. Brüggemeier, 'Risk and Strict Liability: The Distinct Examples of Germany, the United States, and Russia', European Review of Private Law 21 (2013) 923, 939 with further references.

93 Characteristic are, inter alia, Losee v. Buchanan, 51 N.Y. 484 (1873), again a case of an exploding steam boiler: Strict liability "would create a liability which would be the destruction of all civilized society"; and Brown v. Collins, 53 N.H. 442 (1873).

94 Restatement of the Law (Third) Torts: Liability for Physical and Emotional Harm, 2010, sec. 20.

95 Thus, the Second Restatement stipulated liability for plane accidents $(\S 520)$ which has, however, been abolished in the meantime. There are only a few States that enacted statutory regulations of strict liability for ground damage caused by aeroplanes. Cf., e.g., South Carolina Code $\S 55-3-60$.

96 Cf., inter alia, G. T. Schwartz, 'Contributory and Comparative Negligence', Yale Law Journal 87 (1978) 697, at 700 n. 17: "Ultrahazardous activity liability is of almost no practical importance."

Comprehensive Environmental Response, Compensation, and Liability Act (CERCLA). 


\section{Restructuring the Modern Law of Delict}

After this tour d'horizon through the law of delict of the $19^{\text {th }}$ and $20^{\text {th }}$ centuries, it is now time to draw conclusions. This contribution has tried to trace the development from pre-modern liability for typified direct intentional delicts, through universalisation of liability for personal fault ("only fault triggers liability"), to a post-modern quasi-strict enterprise liability. From my point of view, the consequences for re-structuring the delict are as follows: ${ }^{98}$ (I) Restricting fault liability to human conduct, (II) development of the enterprise liability with its three tracks (1) employers' vicarious liability, (2) liability for organisational "fault", (3) special case of strict product liability, and (III) Gefährdungshaftung for increased technical-industrial risks. The latter comprises private persons and enterprises, but here, too, commercial enterprises are at the fore. ${ }^{99}$ At the core, however, is not the reference to the person or enterprise, but the respective technical-industrial risk as the cause of liability.

\subsection{Fault Liability ( fait de l'homme)}

In line with the original intention of the drafters of modern law of delict, fault liability should be limited to human conduct. Also, the mistake of the Japanese and most continental European laws of delict must be avoided: the supposed equal treatment of intentional and negligent injuries. The only thing that these two types of delict have in common is that they both involve human conduct. A sub-division of liability for faute personnelle is the noxal liability of parents for their children needing supervision. ${ }^{100}$

$98 \quad$ I have developed these thoughts in the following three books in particular: Prinzipien des Haftungsrechts (Baden-Baden: Nomos 1999) (English: Principles of Tort Law (London: BIICL 2004/2006)); Haftungsrecht. Struktur, Prinzipien und Schutzbereich (n. 55); Modernising Civil Liability Law in Europe, China, Brazil, and Russia (n. 4), 1-136. The wellknown drafts on the reform of the European law of delict/tort - Principles of European Tort Law (PETL). Text and Commentary (Vienna/New York: Springer 2005) and Draft Common Frame of Reference (DCFR), Book VI: Non-Contractual Liability Arising out of Damage Caused to Another (Sellier/Bruylant/Stämpfli 2009) - could not be considered in greater detail in the scope of this paper. Furthermore, see R. Zimmermann (ed.), Grundstrukturen des Europäischen Deliktsrechts (Baden-Baden: Nomos 2003) and J. Bell \& D. J. Ibbetson, European Legal Development. The Case of Tort Law (Cambridge: CUP 2012).

99 The most important exception as a Gefährdungshaftung of private persons is vehicle owner's liability.

100 French law, however, is markedly different since the seminal Bertrand-judgment: Cour de Cassation civ., 19.2.1997, Dalloz 1997, 265. 


\subsubsection{Intentional Conduct}

In recent times, civil liability for intentional conduct has played a more minor role in litigation. It is, however, very important for the clarification of fundamental structural issues of the law of delict. The three-tier structure of the BG B law of delict can be a starting point for a better understanding of the structure of intentional delicts. It must be changed into a four-tier structure, however.

The first tier consists of three objective elements: conduct, i.e. action or omission, ${ }^{101}$ injury of a protected interest, and causation between both. The familiar principles apply. For the concept of conduct this means: wilful action or omission and age- and health-related ability to commit a delict (discernment/ Deliktsfähigkeit) is presumed. For a long time, no difference was made between injurious conduct and intent (deliberate injury) because of their close historical symbiosis. The second tier consists of the subjective element of intent: deliberate and conscious injury. The third concerns unlawfulness. Each intentional injury of protected legal interests gives rise to a presumption of unlawfulness. In this respect, the doctrine of Erfolgsunrecht does apply here. Unlawfulness lapses if the tortfeasor invokes justification or privileges/defences (consent, self-defence, state of emergency). French law, too, applies faits justificatifs only in cases of intentional conduct (faute délictuelle). The fourth tier contains a specific characteristic of liability for intentional delicts: awareness of wrongdoing. The intentional wrongdoer must not only intend to injure, he or she must also act in the awareness that his/her conduct is unlawful. If they think their conduct is justified, intention is missing. ${ }^{102}$ If the error was avoidable, liability for negligence may apply; if it was unavoidable, no liability exists.

Traditionally, direct violations were at the fore in cases of deliberate injuries. However, indirect infringements can easily be included, provided there is evidence of a corresponding course of action of the tortfeasor. In summary, the intentional delict has the following structure:103

(1) conduct, injury, causation,

(2) intention,

(3) unlawfulness (absence of privileges),

101 In most legal orders, omission is only relevant for liability if an affirmative legal duty to act is in force.

102 As a rule, in German law, intention is not absent in cases of errors about immorality (§ 826 вGв). Knowledge of the factors constituting an infringement of good morals suffices. See Reichsgericht, 29.9.1909, $R G Z$ 72, 4, at 8; Bundesgerichtshof, 24.11.1952, $B G H Z$ 8,83 .

103 On intentional torts in American common law, cf. O. W. Holmes, 'Privilege, Malice, and Intent', Harv. L. Rev. 8 (1894) 1, 11: "the intentional infliction of temporal damage ... is actionable if done without just cause." See generally Restatement of the Law (Third) Torts: Intentional Torts to Persons, Discussion Draft 2014, and J. Finnis, 'Intention in Tort Law', in Owen (ed.), Philosophical Foundations of Tort Law (n. 8), 229. 


\section{(4) awareness of wrongdoing.}

Deliberate injury has further specific characteristics. Primarily, liability insurance is not available. Occasionally, it is combined with sanctions which go beyond compensatory damages: exemplary/punitive damages. Nowadays, it is largely accepted that the employer is also liable for intentional delicts of his/ her employee. ${ }^{104}$ Unlike in negligence, here the private (and public) employer can have a right to recourse. An internationally recognised intentional delict with roots in Natural Law is the violation of basic moral standards ("immorality"), which can also lead to compensation of pure economic loss. ${ }^{105}$

Incorporated enterprises or legal persons are not capable of being at fault in this way i.e. acting with intent. Their liability for third-party damage through manipulative actions of their personnel can only be based on organisational fault (enterprise liability for negligence - § 823 para 1), on employers' vicarious liability for intentional delicts of employees $(\S 831)$ or on corporate liability for intentional delicts of directors and officers $(\S 31) .{ }^{106}$

With the recognition of third-party effects of constitutional fundamental rights on private law, an important new group of cases of intentional unlawful injury to others has developed:107 investigative journalists discovering mafia-style business practices, magazines publishing private photos of

104 Other relevant new groups of cases comprise hate speech in social media and sexual assaults by fellow employees, executives or third persons. On latter cases in common law, cf. Brodie, Enterprise Liability (n. 43), 27 ff. A completely different and spectacular case was the recent crashing of a Germanwing plane in the French Alps on 24.3.2015, deliberately caused by the co-pilot.

105 Contra bonos mores: § 1295 para 2 ABG B, Art. 41 para 2 OR, § 826 BG B. Also, the famous Dutch case Lindenbaum/Cohen in 1919 is a case of intentional causation of loss contrary to public policy (unfair competition): Hoge Raad, 31.1.1919, Nederlandse Jurisprudentie 1919,881 .

106 This is why in the German Diesel scandal damages actions of car buyers against Volkswagen AG cannot be based directly on § 826 в в . Organisational fault ( $\$ 823$ para 1) does not apply here either, as damages for pure economic losses are not recoverable under $\S 823$ para. 1 в в в. The only viable options are liability of Volkswagen AG under $\S 831$ for intentional delicts of its employed engineers as per $\S 826$ (RGZ 87,1 ) or under $\S 31$ for intentional delicts of its directors as per $\S 826$ (Reichsgericht, 17.1.1940, RGZ 163, 21; Bundesgerichtshof, 28.6.2016, NJW 2017, 250). The latter option ( $\$ 826,31)$ has been taken by the Bundesgerichtshof in its landmark decision of 25.5 .2020 , VI ZR 252/19, juris, in the VW Diesel scandal.

107 Fundamental in Germany: Bundesgerichtshof, 25.5.1954, $B G H Z$ 13, 334 - Schacht-letter to the editor; Bundesverfassungsgericht, 15.1.1958, BVerfGE 7, 198 - Lüth; cf. in general: G. Brüggemeier/A. Colombi Ciacchi/G. Comandé (eds.), Fundamental Rights and Private Law in the European Union, 2 vols (Cambridge: CUP 2010). - On the horizontal effects of the EU Charter of Fundamental Rights (in force since 2009) see D. Leczykiewicz, 'Horizontal Application of the Charter of Fundamental Rights', European L. Rev. 38 (2013) 479. 
celebrities, ${ }^{108}$ whistle-blowers reporting on questionable internal matters, ${ }^{109}$ protest demonstrations against traffic density, ${ }^{110}$ climate activists blocking the mining of lignite. In all of these cases, there is a prima facie intentional violation of personality rights or a corresponding intervention into businesses. The crucial question in law-of-delict terms is whether the deliberate injurious conduct is justifiable on constitutional grounds (freedom of the press, right of free speech, right to demonstrate).

However, claims resulting from medical treatments, a large group of cases, are often wrongly characterised as intentional and unlawful (rechtswidrig). The German law of delict, for instance, still regards each of the thousands of medical operations, performed every day in hospitals and doctors' surgeries as a potentially unlawful bodily injury. ${ }^{111}$ Legal disputes centre around the question of effective consent as a reason for exclusion of unlawfulness. ${ }^{12}$ This is the wrong approach, determined by criminal law. Instead, there are three clearly differentiated scenarios: unauthorised treatment, malpractice and incorrect medical information. Only the first case, unauthorised treatment, i.e. knowingly treating the patient without his/her consent or against his/her will, constitutes intentional and unlawful bodily harm (medical battery), these days a fairly rare occurrence. - Malpractice concerns consented and indicated medical treatment. The only issue in this case is whether an injury to the patient was caused by a treatment which was not up to medical standards. This is a case of negligence liability for injury to body or health. ${ }^{113}$ - In the case where the patient is inadequately informed about the risks of treatment, the focus is on the patient's autonomy. If the patient has not been sufficiently informed beforehand about the risks involved in the respective operation, this affects his/her right to self-determination about his bodily and mental integrity. In these cases, there may be a claim for compensation of pecuniary and nonpecuniary loss on the grounds of (intentional or) negligent infringement of the patient's autonomy.114

108 Cf. European Court of Human Rights (ECtHR), 24.6.2004, Caroline von Hannover v. Germany (No 1) 40 E HRR 1.

109 Cf. ECtHR, 21.7.2011, Heinisch v. Germany, AppNo. 28274/08.

110 Cf. European Court of Justice, Case C-112/oo, Schmidberger (2003] ECR I-5659.

111 Since Reichsgericht, 27.5.1908, RGZ 68, 431.

112 As one example of many, cf. H. Koziol, 'Die Einwilligung zu medizinischen Eingriffen', Juristische Blätter 2016, 617.

113 This is also the unanimous approach in the Common Law countries. Cf., inter alia, M. Jones, Medical Negligence (London: Sweet \& Maxwell $5^{\text {th }}$ ed., 2017).

114 In more detail, cf. Brüggemeier, Haftungsrecht (n. 55), 455-510; for a comparative study see K. Oliphant \& R. W. Wright (eds.), Medical Malpractice and Compensation in Global Perspective (Berlin: de Gruyter 2013). - Whether in medical cases contract law and/or law 


\subsubsection{Negligent Conduct \\ 4.1.2.1 Accidents}

Internationally, negligence liability is the law of accidents: direct injury to another person caused by carelessness. ${ }^{115}$ This especially concerns traffic accidents, ${ }^{116}$ accidents in sports, and everyday life. This category also includes the negligent performance of professional services, e.g. by doctors. Compared with the complex structure of the intentional delict, the negligence delict has a simple two-stage structure. The first stage consists- just like intentional delicts - of the well-known three objective elements: conduct, infringement of a legal interest, and causation. The second stage concerns the fault of negligence: the actor has not shown the care that was objectively appropriate in the concrete situation in the given circumstances. In civil law countries, the normative standard of due care is determined in casu by the professional judge. The factual injurious conduct that has been established by proof either meets this standard or falls short of it. The latter is a case of negligence.

Damnum culpa datum. This is the delict of negligence in a nutshell. Under no circumstances is any form of unlawfulness of the infringement of interests a requirement of this delict. As Ulpian stated in the 2nd century AD: It is the negligent manner of the injurious conduct which constitutes the wrong. ${ }^{117} \mathrm{In}$ other words: for negligence liability, Verhaltensunrecht applies. The ambiguity of terms in this field is, amongst other things, a result of the following circumstances: the after-effects of the Enlightenment Natural Law doctrine which equates infringements of rights with unlawfulness irrespective of fault and the fact that unlawfulness and wrongfulness are not identical concepts. Wrongfulness defines the forbidden action (civil wrong/onrechtmatige daad/fatto illecito). ${ }^{118}$ In German law of delict, the following are especially wrongful acts: (i) intentional-unlawful or negligent injury of protected interests and rights of others, ${ }^{119}$ (ii) culpable breach of statutory duty, and (iii) intentional and

of delict/tort is applied, depends on the specific structure of the respective national health system.

115 For an empirical study cf. D. Dewees/D. Duff/M. Trebilcock, Exploring the Domain of Accident Law (Oxford: OUP 1996).

116 In most countries of continental Europe, this has been augmented by the special regime of Gefährdungshaftung of automobile owners.

117 See above, note 13 .

118 See generally J. H. Nieuwenhuis, 'Wat is een onrechtmatige daad? Europese perspectiven', RM Themis 1998, 242.

119 This differentiation is even made in the casuistic American law of torts. Cf. Vosburg v. Putney, 50 NW 403 (Wis 1891): "[In personal injury cases] the rule is correctly stated, ..., that plaintiff must show either that the intention was unlawful, or that the defendant is in fault." Cf. also Holmes (n. 103). 
immoral causation of losses. ${ }^{120}$ The narrow term "unlawfulness" in § 823 para 1, like "immorality" (contra bonos mores) in $\S 826$, is merely a technical component within the structure of the intentional delict. ${ }^{121}$ Finally, it must be stressed again in this civil law context that negligence in everyday accidents does not require any duty of care. This only applies in cases of remote injuries. And there, it has nothing to do with unlawfulness or negligence as fault, but with the imputation of remote consequences to a specific action (Palsgraf doctrine). This will be addressed in the next section.

\subsubsection{Remoteness of Damage}

Remote harms, which are mainly connected with enterprise liability (as liability for employees' delicts or for organisational fault), pose a general problem of negligence liability, so they must also be included here. For injuries more remote in space and time, causation is a necessary, but not a sufficient ground for liability. In addition, the remote damage of interests must here be attributable to the acting person or enterprise. It must be "within the risk", i.e. be connected with the typical risks of the respective action or activity. ${ }^{122}$ The injury must be qualified as a foreseeable and not a completely improbable consequence of the conduct or activity. In international practice, this attribution happens by establishing a duty of care. Germanic laws also applied such terms as the 'protective purpose of the norm' (Schutzzweck der Norm) or 'context of unlawfulness' (Rechtswidrigkeitszusammenhang), French law used the term 'relativité aquilienne, ${ }^{123}$ Whatever the label, what the judge is in effect doing is deciding on the personal, spatial and objective scope of protection: which remote persons are protected against which injuries to which interest.

120 In the Austrian Civil Code (ABGB), the wrongful action is defined as culpable, i.e. intentional or negligent, causation of damage ( $\$ 1294)$ and as damage which is caused intentionally contrary to public policy/good morals (§ 1295).

121 The term unlawfulness in the law of delict must be distinguished from "unlawfulness" in other subfields of law. Thus, in property law, any situation that is contrary to the allocational content (Zuweisungsgehalt) of a property right in rem, is unlawful: e.g., possession in good faith of an object that belongs to somebody else.

122 On the 'harm-within-the-risk test' cf., inter alia, K. Abraham, The Forms and Functions of Tort Law ( $5^{\text {th }}$ edn., Westbury: Foundation Press 2017) chap. 6, I B.

123 See, inter alia, J. Limpens, 'La théorie dite de la "responsabilité aquilienne“ ', in Mélanges R. Savatier (Paris: Dalloz 1965), 539 . 


\subsubsection{Examples of Cases in Common Law and Civil Law}

Prime examples in Common Law are the American Palsgraf case and the Australian Wagon Mound cases. ${ }^{124}$

In the bizarre New York Palsgraf case of 1928, ${ }^{125}$ the Civil Jury had established the carelessness of two railway employees who wanted to help a passenger with a parcel (containing firecrackers) under his arm onto the departing train (one pulling the passenger from the inside, the other pushing from the outside). ${ }^{126}$ Causing the fall and destruction of the passenger's parcel constituted a negligent direct damage to property. However, how should one deal with the consequences of the exploding firecrackers for Mrs. Palsgraf, who was injured while waiting for her train at a certain distance? It is hard to argue that the risk of exploding firecrackers is among the risks caused by the conduct of railway guards who tried to help a passenger with a parcel board a departing train. ${ }^{127}$ Cardozo C. J., writing for the majority of the N. Y. Court of Appeals, stated that negligence is a 'term of relation' and he denied a protective relationship (duty of care) between the railway guards and Mrs. Palsgraf.

In the Australian example, during the refuelling operations of the Wagon Mound vessel in the harbour of Sydney, overflowing heavy oil spilled onto the water surface due to the carelessness of the crew. ${ }^{128}$ This is obviously a case of negligent conduct causing a pollution. But what about the fire on the other side of the harbour? Causation is undisputed. Is the fire and its consequences

124 A well-known English example is Dorset Yacht Co Ltd v. Home Office [1970] AC 1004, [1970] 2 All ER 294 (HL). This is a case of State liability, where the common law principles of negligence liability applied. Due to inattentive supervision, juvenile delinquents were able to escape at night from an approved school situated on an island. They stole a sailing boat in order to leave the island. In this process, the sailing boat was damaged. Court of Appeal and House of Lords acknowledged a duty of care which includes the risk that escaping youths cause damage to sailing boats of the local yachting club.

125 Cf. above, note 57.

126 In light of the facts this was not without problems. Cardozo CJ had major doubts. However, he was bound to this conclusion for procedural reasons. The true wrongdoer, who had created the risk for the people on the crowded platform, was the passenger with his parcel full of firecrackers.

127 Nonetheless, both lower courts in New York had decided in favour of the plaintiff, before the Court of Appeals rejected the claim, albeit with a narrow majority of 4 to 3 . The three votes in favour were based on an English common law doctrine which for the American law was now overruled through the Palsgrafjudgment. According to this English doctrine, also unforeseeable consequences of an action were attributable as long as there was a close spatial and temporal connection (so-called Polemis doctrine). Cf. Re Polemis \& Furness, Withy \& Co. Ltd. [1921] 3 кв 560 (CA).

128 Cf. above note 74. With the Wagon Mound No. 1 Decision, the Privy Council, too, rejected the Polemis doctrine. 
attributable? That oil and fire would combine is not beyond the imagination. Other circumstances, however, caused additional problems: to begin with, the oil was blown to the other side of the harbour where welding works were taking place on a dockyard. Also, the heavy oil, which does not ignite easily, was set alight by flying sparks stemming from the welding works which hit some dry rubbish on the oily surface. A borderline case indeed! Not surprisingly, the House of Lords (acting as Privy Council for the Commonwealth Countries) in two subsequent decisions (with different participating Law Lords!) ruled once for (foreseeability affirmed) and once against (foreseeability negated) attribution.

Next, two examples from European civil law will be examined, both concerning the donation of kidneys:

In the German case, a 13-year old girl was taken to hospital after a sports accident. An injury to the left kidney was diagnosed and the kidney removed. Then it was discovered that the girl had only had one kidney from birth. On doctors' advice, the mother decided to donate a kidney. The mother sued the hospital for damages because she had "sacrificed" a kidney. Malpractice regarding the child was free from doubt (primary injury). But can the mother's voluntary sacrifice of a kidney (secondary injury) still be attributed to the doctor's malpractice? In all three instances, the courts affirmed the connection. ${ }^{129}$

In the famous Danish Veedfald case, someone donated a kidney to his brother who suffered from kidney problems. In the public hospital, preparations were made for the transplantation. In the process, the donor's kidney was rinsed, but the washing-up liquid proved to be defective, which rendered the kidney unusable. The intended recipient of the kidney sued the hospital for damages and compensation for pain and suffering. The case was brought before the European Court of Justice (ECJ), where applicability of EU product liability law was affirmed.130 Beyond that, however, the ECJ left open all issues of type of damage and injured party. The rinsing liquid had been produced by the hospital itself but for internal use only and was not intended for commercial marketing. Treatment with the liquid had damaged the kidney, which was in the possession of the hospital, but presumably still property of the donor (primary

129 Bundesgerichtshof, 30.6.1987, BG HZ 101, 215. It is characteristic of the state of the German law of delict that the judges made great efforts to substantiate an 'unlawfulness' of the delict committed against the mother (p. 224).

130 ECJ, Case C-203/99, Veedfald v. Århus Amtskommune (2001] ECR I-3569; Haftpflicht Intern'l 2003, 13 with comment by H. C. Taschner. 
direct injury). ${ }^{131}$ The recipient was indirectly damaged in his health. A possible improvement of his medical condition was prevented because the transplantation could not take place. In the case of negligence of the hospital, the manufacturer's or service provider's fault liability for pecuniary and non-pecuniary loss to the plaintiff would apply. ${ }^{132}$

The setting of standards of due care has sometimes been described as a "negligence lottery", 133 and this is even more true for the determination of the protective scope of a duty of care. Various aspects can be taken into account: foreseeability, cost-benefit, type of legally protected interests etc. In this respect, one must agree with the House of Lords, which decided in a case of auditor's liability: remote infringements can be attributed to the party who caused them, provided it is "just, fair and reasonable" to do so. ${ }^{134}$ This three-fold formula of indeterminacy - the so-called Caparo tripartite test - illustrates the problem correctly, but offers little to reduce this indeterminacy.

\subsubsection{Framing Groups of Cases}

Jurisprudence and legal scholarship are trying to remove the uncertainties of establishing the scope of protection by establishing groups of cases with specific determining factors. One of these is cases of nervous shock: An accident involving death or severe injury has been caused by negligence. Voluntary helpers rushing to the scene or close relatives being notified of the accident experience post-traumatic stress disorder. Defining the group of protected persons is difficult. Which relatives are protected? Are professional helpers, i.e. police and firemen, excluded? These questions were discussed in exemplary fashion after the disaster in Sheffield's Hillsborough football stadium in $1989 .{ }^{135}$ A further scenario are power-outage or broken cable cases: During earthmoving operations, the operator of an excavator damages an energy supply line thus causing a power-outage. This first constitutes direct damage to property

131 On the legal treatment of destruction of extracted and stored parts of the human body, see the „sperm cases“: Bundesgerichtshof, 9.11.1993, $B G H Z$ 124, 52; J. Yearworth and Others $v$ North Bristol NHS Trust (2009] EWCA Civ 37, 2009 WL 6517; and generally cf. M. Quigley, Self-Ownership, Property Rights, and the Human Body (Cambridge: CUP 2020).

$13^{2}$ Because of many questions not being clarified by the ECJ, in Denmark the lawsuit was eventually settled out of court.

133 Cf. n. 64.

134 Caparo Industries plc v. Dickman [1990] 2 AC 605, at 616-618. For a recent clarification that the Caparo test applies in novel cases only, see Robinson $v$ Chief Constable of West Yorkshire Police [2018] U KSC.

135 Alcock and Others v. Chief Constable of South Yorkshire Police [1991] 3 WLR 1057; White and Others v. Chief Constable of South Yorkshire Police [1998] U K HL 45; Frost v. Chief Constable of South Yorkshire Police [1999] ICR 216. 
(supply line). Secondly, there are households and enterprises which lose their electricity supply. Under German law, according to the enumerative $§ 823$ para 1, these affected parties can only claim compensation for property damage. However, loss of profit resulting from the halt in production is not compensable. ${ }^{136}$

In summary, the basic structure of the negligence delict is as follows:

(1) conduct, injury to a protected interest, causation,

(2) negligence,

(3) duty of care in cases of remoteness (scope of liability). ${ }^{137}$

For conduct (action or omission) and causation the general principles apply.

\subsubsection{Wealth (Vermögen) as a Protected Interest}

It should be noted that legally protected interests need not be enumerated. This unnecessarily restricts the further development of law. However, one particular problem, already mentioned in the power-outage cases, must be taken up again in this context: To what extent does wealth constitute an interest protected against negligence? In other words, are pure economic losses recoverable?138 With prominent exceptions such as France and Japan, in most countries, compensation here is subject to certain conditions: gross negligence or unlawful intention, culpable breach of a statutory duty, or deliberate immoral conduct. These conditions should be clarified through statutory provisions. In this context, professional liability is a special case group: an architect (employed or self-employed) drawing up defective plans for a house owner who wants to sell his house. The buyer of the house, after discovering the overlooked defects, sues the architect for the excessive purchase price or the unexpected additional costs. ${ }^{139}$ Auditors drawing up a final report for companies

136 Cf. Bundesgerichtshof, 9.12.1958, BGHZ 29, 65 and 4.2.1964, BGHZ 41, 123. - For the English position, see the famous case of Spartan Steel \& Alloys Ltd $v$ Martin \& Co (Contractors) Ltd [1973] QB 27.

137 For a similar approach cf. the definition of the tort of negligence by G. T. Schwartz in his draft for a third Restatement: "An actor is subject to liability for negligent conduct that is a legal cause of physical harm." Cf. Restatement (Third) of Torts: Liability for Physical Harm (Basic Principles), Tentative Draft No. 1, 2001, sec. 3.

138 Cf. V. V. Palmer, 'A Comparative Law Sketch of Pure Economic Loss', in Bussani/Sebok (eds.), Comparative Tort Law (n. 4), 3oo; W. H. van Boom/H. Koziol/C. A. Witting (eds.), Pure Economic Loss (Vienna/New York: Springer 2004); but see also P. Cane, Tort Law and Economic Interests (Oxford: OUP 1991).

139 Cf. Bundesgerichtshof, 10.11.1994, $B G H Z$ 127, 378 - roof truss (solution via contract with protective effect for third parties); cf. G. Teubner, Expertise als soziale Institution, in Brüggemeier (ed.), Liber Amicorum Eike Schmidt (Karlsruhe: C. F. Müller 2005) 303. - On the German quasi-contractual approach of reliance liability see C. W. Canaris, Die Vertrauenshaftung im deutschen Privatrecht (Munich: Beck, 1971). 
listed on the stock market, which serves as a guideline for investors and shareholders. ${ }^{140}$ Art experts writing a certificate of authenticity for a painting, which is the basis of its value in the art market. Because of the financial importance and the institutional trust put in professional expertise, there has been an increasing readiness to allow recovery in such cases. However, many of the details are still under discussion.

\subsection{Enterprise Liability}

4.2.1 Employers' Vicarious Liability

The first track of enterprise liability is a combination of a personal delict (of the employee) and strict liability of the employer/enterprise. ${ }^{141}$ This type of liability is mainly justified with the following arguments: that the entrepreneur creates the risk of damage to third parties by launching the business; that he can control the risk through his organisational powers; that he draws the profit from the undertaking, and, last but not least, that - contrary to the individual employee - he can get insurance coverage for these risks of losses (employer's liability insurance); and that he can spread the costs through his prices. ${ }^{142}$ The employee is the dependent jobholder. ${ }^{143}$ It is of minor importance to what extent he or she acts on instruction in the everyday execution of his/her individual tasks. Neither does the professional qualification of the employed person, e.g. as doctor, lawyer, architect, etc., preclude the use of the term of employee. He or she must have acted "within the scope of employment". For an employee's delict, the above principles of liability for intentional or negligent wrongs are applicable. This private employer's vicarious liability is liability of businesses. Therefore, non-profit organisations should come under less strict forms of liability, for instance according to the model of the Germanic laws (e.g. $\S 831$ BGB). Public employers'/State Authorities' liability has been regulated by special rules in most (continental) European countries and in Japan.

A controversial socio-political question is the employee's external liability towards injured third parties, especially in cases of employers' insolvency and

140 Cf., inter alia, H. Koziol/W. Doralt (eds.), Abschlussprüfer. Haftung und Versicherung (Vienna/New York: Springer 2004).

141 Arriving at the same conclusions: Principles of European Tort Law (n. 98), Art. 6:102 and Draft Common Frame of Reference (n. 95), vi.-3:201. - On common law, cf. Brodie, Enterprise Liability (n. 43).

142 For a locus classicus, cf. A. A. Ehrenzweig, Negligence without Fault. Trends toward an Enterprise Liability for Insurable Loss (Berkeley: UC California Press, 1951).

143 Managers (directors and officers) are not classified as employees. On the internal and external liability of managers cf. S. F. Deakin/H. Koziol/O. Riss (eds), Directors and Officers (D\&O) Liability: Economic Analysis (Berlin: de Gruyter 2017). 
lack of liability insurance. In accordance with French ${ }^{144}$ and Scandinavian ${ }^{145}$ law, liability should be excluded in cases of ordinary negligence. The same path is followed by Japanese and Chinese law. ${ }^{146}$ In cases of intentional delicts, subsidiary external liability as well as the right of recourse of the employer should apply.

4.2 .2

Liability for Organisational Fault (défault d'organisation/colpa d'apparato)

This is quasi-strict liability of commercial enterprises, justified by aspects of cost internalisation and cost spreading. Fair competition and efficient prevention of injuries can only be ensured if the costs of a business activity can be attributed to the source. The type of liability, outlined here, developed under the umbrella of fault liability, which explains the name. But it is no longer connected in any way to personal misconduct. The focus is not on individual conduct but on business activities, which explains why incorporated enterprises normally incapable of being at fault in the traditional sense - are also directly liable. This is civil quasi-strict liability, i.e. if causation has been established, it is up to the enterprise to prove that the damage was unavoidable (reversal of the burden of proof). The point here is to determine what was possible and reasonable - from a financial, technical and organisational perspective for the enterprise to prevent the injury. Cost-benefit considerations (Learned Hand test) play an important role, as do consumer expectations, regulatory compliance, and existence of a development risk. Criminal interventions of third parties (sabotage) may also relieve liability.

First and foremost, this liability applies to manufacturing enterprises (producers' liability, environmental liability), but it may also concern service providers. The Danish Veedfald case was still a marginal case between producers' liability and liability of providers of medical services. ${ }^{147}$ A more recent German-French example of liability of service providers is a case involving a certification company. Under the EU Regulation governing medical devices, ${ }^{148}$ private certification institutes accredited by the European Commission must certify manufacturers of medical products and supervise their production. A French producer of breast implants circumvented the inspections of his

\footnotetext{
144 Since the seminal Costedoat judgment; cf. above n. 54 .

145 Under Swedish law, employees are only liable if there are "particular reasons for such liability". Tort Liability Act 1972, ch. 4, sec. 1.

146 C. Ding, Development (n. 46), 67, $92 \mathrm{ff}$.

147 Cf. above n. 130.

148 Directive 93/42/EEC concerning medical devices, OJ $1993 \mathrm{~L} \mathrm{169/1;} \mathrm{in} \mathrm{the} \mathrm{meantime,} \mathrm{re-}$ placed by Regulation (EU) 2017/745 on medical devices of 5.4.2017, OJ $2017 \mathrm{~L} \mathrm{117/1.}$
} 
German certification institute through criminal manoeuvres. After the producer had gone bankrupt, affected women in Europe and South America, who had received implants that were dangerous to their health, sued the certification institute. The EU regulatory law of medical products aims to protect patients. This gives rise to the question of liability of the German certification company on the grounds of insufficient monitoring. ${ }^{149}$ The same problem came up recently in Brumadinho, Brazil, where a dam burst in January 2019, with more than 200 people killed. Again, the focus is on a German certification institute which had carried out the inspection and supervision.

The structure of this type of organisational liability can be summarised as follows: 150

(1) business activity, injury, causation,

(2) presumed avoidability of injury,

(3) duty of care (scope of protection).

\subsubsection{Product Liability}

In the 196os, so-called "strict product liability" as a special path of "noncontractual producers' liability" began to establish itself in the USA and shortly afterwards in Europe. In the USA, it evolved from "contractual warranty liability" and combined the directness of the actions in tort with the strictness of contractual warranty claims. This explains its characteristics: defective product, producer and seller as addressees of liability, no-fault liability. This product liability was removed from its contract law context and incorporated into the tort system. Contrary to its broad definition, however, this product liability is restricted to manufacturing defects. Errors in product design or in the instructions to customers fall under general negligence liability. ${ }^{151}$

149 Liability was denied in Germany by the Bundesgerichtshof, 22.6.2017, Neue Juristische Wochenschrift 2017, 2617 (cf. G. Brüggemeier, JuristenZeitung 2018, 191). In France, the Cour de Cassation, in the first of two lawsuits, quashed the decision by the previous instance which had dismissed the claim (Cour de cassation, 10.10.2018 - affaire PIP).

150 Cf. also the regulatory proposals in the French reform projects (Avant-Projet Catala (n. 2), Art. 1353 and Projet de réforme 2017 (n. 2), Art. 1242-1), and in the Principles of European Tort Law (n. 98), Art. 4:202 (enterprise liability). - For US law approaches to enterprise liability which originated in Legal Realism, cf., among others, Ehrenzweig, Negligence Without Fault (n. 142); G. W. Priest, 'The Invention of Enterprise Liability', Journal of Legal Studies 14 (1985) 461; American Law Institute (ALI), Reporters' Study: Enterprise Responsibility for Personal Injury, 2 vols., 1991; V. E. Nolan \& E. Ursin, Understanding Enterprise Liability (Philadelphia: Temple UP 1995); G. C. Keating, 'The Theory of Enterprise Liability and Common Law Strict Liability', Vanderbilt Law Review 54 (2001) 1285.

151 Cf. Henningsen v. Bloomfield Motors, 161 A.2d 69 (N.J. 1960); Greenman v. Yuba Power Products, 377 P.2d 897 (Cal. 1963); Restatement of the Law (Second) Torts, 1965, § 402A; now: 
After long period of preparation, Europe adopted its own version. ${ }^{152}$ The freedom of movement of goods in the internal market was to be complemented by an EU-wide protection of the consumer. Unlike in US law, Directive $85 / 374$ intended strict liability also for design and instruction defects. Development risks are not included. Liability is with manufacturers in, and importers into, the European Economic Area. ${ }^{153}$ Retailer liability is subsidiary. Personal injuries and damage to objects, only if they are privately used, are compensable. Damage to commercially-used property and consequential loss are excluded and remain under producers' fault liability. In spite of the focus on personal injury, damages for pain and suffering are not provided for. ${ }^{154}$ This strict product liability has been internationally adopted as a special path of enterprise liability. ${ }^{155}$ Japan, in 1994, also adopted an Act on Product Liability, which was inspired by European law, but with a much broader scope of compensable losses. ${ }^{156}$

Basically, strict product liability contains four elements: Product, (manufacturing) defect, injury/damage, causation.

\subsection{Liability for Increased Industrial-Technical Risks (mise en risque)}

In organisational liability of enterprises, the concept of fault continues to find expression, albeit in a largely nominal form. In respect of hybrid liability for defective products, it is not clear whether this is a case of strict liability or fault

Restatement (Third) Products Liability, 1998; cf. in general D. G. Owen, Products Liability (West/Thomson $3^{\text {rd }}$ edn. 2014).

152 Directive on liability for defective products (85/374/EEC); cf. H. C. Taschner, Produkthaftung (Munich: Beck 1986). - An important national predecessor was liability for pharmaceuticals in Germany, introduced in 1976 after the Thalidomid/Contergan catastrophe.

153 The European Economic Area (EEA) comprises the EU Member States plus Norway, Iceland and Liechtenstein.

154 In 2002, as part of an amendment to the law of damages (n. 87), Germany introduced the right to damages for pain and suffering in its Product Liability Act, the national implementation of the Directive. This rule is, however, in breach of EU law and therefore in applicable: Following the jurisprudence of the European Court of Justice, the Product Liability Directive comprises a maximum harmonisation which excludes any alteration or extension by the Member States. Cf. G. Brüggemeier, Tort Law in the European Union (Alphen aan de Rijn: Wolters Kluwer, $2^{\text {nd }}$ edn 2018) 199.

155 Cf. M. Reimann, 'Product Liability in a Global Context: The Hollow Victory of the European Model', European Review of Private Law 11 (2003) 128, and H. Koziol/M. D. Green/ M. Lunney/K. Oliphant/Yang Lixin (eds), Product Liability. Fundamental Questions in a Comparative Perspective (Berlin: de Gruyter 2017).

${ }_{15} 6$ On Japanese, Korean and Chinese strict product liability law cf. Koziol/Green/Lunney/ Oliphant/Yang Lixin (n. 155). 
liability in disguise. ${ }^{157}$ In the case of liability for industrial-technical risks, the problem of fault does not come into the picture at all. ${ }^{158}$ Both the French path of general no-fault liability of keepers of objects ${ }^{159}$ and the common law path of holding on to the tort of negligence seem to be in need of correction.

\subsubsection{Gefährdungshaftung: Statutes and General Clause}

In continental Europe and Japan special legislation of Gefährdungshaftung for selected risks has become established. ${ }^{160}$ A representative example is vehicle owners' liability with its combination of no-fault liability, obligatory liability insurance, liability ceilings, and admittance of the defence of contributory negligence by the victim. ${ }^{161}$ Aviation traffic is, in addition to national law, regulated by international conventions - Warsaw Convention/Montreal Protocol but limited to the protection of passengers' bodily integrity and property. The Montreal regulations have become directly applicable law in the European Union. ${ }^{162}$ As far as EU law is concerned, the same principles apply to accidents in sea transport. ${ }^{163}$ Irrespective of national regulations of specific technical risks and their analogue application to comparable risks, ${ }^{164}$ there is the basic problem of a general clause of Gefährdungshaftung for high-risk activities. ${ }^{165}$

157 Cf. above in the text and Restatement of the Law (Third) Products Liability, 1998.

158 Contrary to the predominant Swiss doctrine, there is no room for unlawfulness in this context. Gefährdungshaftung is about the materialisation of technical risks. The law of delict refers to human conduct, regardless of whether the focus is on the causation of injury (Erfolgsunrecht) or the infringing conduct (Verhaltensunrecht). On the Swiss law of delict, cf. F. Werro, La responsabilité civile (Bern: Stämpfli $3^{\text {rd }}$ edn. 2017); W. Fellmann \& A. Kottmann, Schweizerisches Haftpflichtrecht (vol. I, Bern: Stämpfli 2012).

159 As per Art. 1384 para 1 C.civ.; see also above in the text.

160 For comparative European surveys cf. B. A. Koch/H. Koziol (eds.), Unification of Tort Law: Strict Liability (Vienna/New York: Springer 2002); F. Werro/V. V. Palmer (eds.), The Boundaries of Strict Liability in European Tort Law (Cambridge: CUP 2004); see also C. Oertel, Objektive Haftung in Europa (Tübingen: Mohr Siebeck 2010). - On Japan, cf. Matsumoto, 'Tort Law in Japan' (n. 29).

161 As a European survey, cf. Ernst (ed.), The Development of Traffic Liability (n. 35).

162 Regulation (EC) No 889/2002 on air carrier liability in the event of accidents, OJ 2002 $\mathrm{L} 140 / 2$.

163 Regulation (EC) No. 392/2009 on the liability of carriers of passengers by sea in the event of accidents, OJ $2009 \mathrm{~L} \mathrm{131/24}$. With this regulation, the Athens Convention of 1974 and its amendment by Protocol of 2002 were transposed into EU law.

164 Analogy is applied in Austria, but rejected in Germany (Reichsgericht, 11.1.1912, RGZ 78, 171) and Japan. Cf. H. Koziol, 'Umfassende Gefährdungshaftung durch Analogie?' in Festschrift W. Wilburg (Graz: Leykam 1975) 173.

165 For a foundational and comparative survey cf. M. Will, Quellen erhöhter Gefahr (Munich: Beck 1980); see also G. Schamps, La mise en danger: Un concept fondateur d'un principe général de responsabilité (Brussels/Paris: Bruylant/LGDJ 1998). 
After lengthy discussions, the European Group of Tort Law in Vienna agreed on a clause for "abnormally dangerous activities", following the model of the American Restatements. ${ }^{166}$ As a statutory provision, the general clause has a long tradition in Russia, starting with $\S 404$ of the Soviet Civil Code of 1922. Most recent is the regulation in the Brazilian Civil Code of 2002. ${ }^{167}$ In my opinion, such a general clause supplementing special regulations of Gefährdungshaftung is fundamentally appropriate. The groups of cases covered are to be determined as a substructure by national jurisprudence and legal scholarship. The focus should be on industrial-technical risks involving increased danger for persons, animals, objects and environment. Exemptions from liability such as force majeure should be listed, reasons for reduced liability such as contributory negligence should be acknowledged and liability insurance protection should be a prerequisite. It is a characteristic of civil liability law that unspecific norms are substantiated and developed by case law. The legislator can intervene, however, should there be economically-undesired disadvantages (over-deterrence).

\subsubsection{The Special Case of Nuclear Energy}

Liability for nuclear accidents is a pressing legal problem, which is beyond the scope of conventional Gefährdungshaftung. Apart from operating companies and a risk pool of insurers and reinsurers, the State acts as service provider. In 1959, Germany passed an Atomic Energy Act, but its liability rules were given a new legal basis by the Paris Convention on Third Party Liability in the Field of Nuclear Energy, concluded in 1960 and in force since 1968 (and the Brussels Convention relating to civil liability in the field of maritime carriage of nuclear materials of 1971). ${ }^{168}$ Gefährdungshaftung is the starting point. Compensation claims for "damage caused by a nuclear incident" are directed against the proprietor of the nuclear plant or vessel. Nor is liability excluded in cases of armed

166 Principles of European Tort Law, Art. 5:101; likewise Avant-Projet Catala (n. 2), Art. 1362 (activité anormalement dangereuse); cf. also H. Kötz, 'Gefährdungshaftung', in Bundesminister für Justiz (ed.), Gutachten und Vorschläge (n. 2), vol.2, 1779.

167 Brazilian Civil Code, Art. 927 para 2: "The obligation to repair the damage will exist, regardless of fault, in the cases specified by law or when the activity normally carried out by the person who caused the damage entails, by its nature, risk to the rights of others." - On both, the Russian and Brazilian general clause, cf. Brüggemeier, Modernising Civil Liability Law (n. 4).

168 The Paris Convention has been ratified by 16 countries. The rival Vienna Convention on civil liability for nuclear damage (1963) has primarily been adopted by the former Eastern bloc countries. Notwithstanding a number of additional protocols and supplemental agreements, the patchwork of atomic liability legislation has not been harmonised to this day. 
conflicts, hostilities or major natural catastrophes. Compensation covers personal injury and property damage. Latterly, environmental damage and nonpecuniary losses (damages for pain and suffering) have been included as well. In the Brussels Additional Protocol of 2004, minimum liability has been fixed at 700 million Euros, the largest part of which is covered by the obligation of private enterprises to take out insurance coverage against such risks. In addition, the State in question has to provide public funds (so-called "indemnification obligation") to cover damages of up to 1.2 billion Euros. In cases where the damage caused by a nuclear accident exceeds 1.2 billion Euros, a further 300 million are covered by a solidarity fund to which all Signatory States contribute. This would compensate damages up to 1.5 billion Euros. The Signatory States can exceed this minimum liability. In Germany and Japan, for instance, liability of the operating company is unlimited. In case of its insolvency, recourse must be sought from the State as a result of its obligation to indemnify. Under German law, this is limited to 2.5 billion Euros, after deducting any benefits from private sources ( $\$ 34$ Atomic Energy Act).

The different national maximum liability limits are the main problem of liability for nuclear accidents in Europe. ${ }^{169}$ In numerous European countries because of the differences between the Paris and the Vienna conventions on liability for nuclear damage and, even more importantly, the fact that the Brussels Convention of 2004 has still not entered into force - these maximum liability amounts merely run into millions. According to conservative estimates, a major nuclear disaster in central Europe would cause damage in the range of three-digit billions. ${ }^{170}$ In Belgium, for instance, where a number of old nuclear power plants are in operation, maximum liability is 1.2 billion Euros. There is no indemnification obligation of the State. So this would be the maximum amount of damage that could be claimed from the Belgian risk pool consisting of the operating company, insurers and reinsurers. In France with its 58 nuclear power stations, maximum liability is even limited to 700 million Euros. In many East European countries, it is lower still. The remaining damage would have to be borne by the victims in the country of the nuclear accident and in its neighbouring areas. In the Belgian example, the German Federal Government would have to compensate German victims to the maximum of the national of indemnification obligation ( 2.5 billion Euros). If the damage amounted to 100 billion Euros, only a fraction would be compensated.

169 Cf. H. Gaßner/K. M. Groth/W. Siederer, Atomhaftung in Europa und Deutschland - Defizite und Empfehlungen zur Fortentwicklung, Gutachten im Auftrag der Bundestagsfraktion Bündnis 9o/Die Grünen, 2013, with further references.

170 The costs of Fukushima in 2011 are estimated at 185 billion Euros, of Chernobyl in 1986 at 200 billion Euros. 
Considering these circumstances, the harmonisation of nuclear liability legislation within the EU, including appropriate maximum liability limits, is long overdue. The liability share of the operating company and insurance pool must be increased. Indemnification by the respective home country must be replaced by a collective State compensation fund contributed to by all EU countries that are still or increasingly using nuclear energy for civil (or even for mere research) purposes. In 2007, the EU Commission made a first step towards harmonising nuclear liability. ${ }^{171}$ Results, however, are not yet in sight.

Liability for the consequences of a nuclear accident is an example of a technical risk, initiated by politics and implemented by the energy industry, which exceeds the limits of private liability and insurance law. ${ }^{172}$ Notwithstanding the much-proclaimed channelling of liability to the originator, the operator of the nuclear power plant, this scenario involves a dimension of risk exposure which can only be absorbed by collective State compensation funds. ${ }^{173}$ Under these circumstances, traditional liability law issues such as jurisdictional competence and applicability of national laws are losing their importance.

$\begin{array}{lll}\text { Fault Liability } & \text { Enterprise Liability } & \text { Gefährdungshaftung } \\ \text { Delict } & \text { Quasi-Delict } & \text { Non-Delict }\end{array}$

1. Intentional Delict

2. Negligence Delict

1. Employers' Vicarious

Special Statutes Liability General Clause?

2. Organisational [Human misconduct] Liability

3. Product Liability [Admission of risk \& social pressure to accept the risk]

[Internalising \& spreading of costs]

171 Cf. N. Pelzer (ed.), Europäisches Atomhaftungsrecht im Umbruch (Baden-Baden: Nomos 2010).

172 The Belgian operators of nuclear power plants actually face problems in financing insurance coverage.

173 These were also the considerations of the U.S. Supreme Court in 1978, when it affirmed the constitutionality of limited liability in the US Atomic Energy Act only because the Act provided for Congress to allocate public funding for further compensation payments. Cf. Duke Power Co. v. Carolina Environmental Study Group, Inc., 438 U.S. 59 (1978). 


\section{5} Summary

A restatement of this postmodern law of delict has to start with a general principle: Where there is an attributable injury to another person, an obligation to compensate ensues. This would be the up-to-date restatement of the damnum iniuria datum-formula of the lex Aquilia. This general principle, however, contains neither unlawfulness nor fault nor duty of care. Instead, the most important reasons for attribution are referred to: personal fault, defective business activities, and the creation of increased technical risks. ${ }^{174}$ Under the first reason for attribution - personal fault -, the classic delict (fait de l'homme) contains the four basic elements: conduct, injury/damage, causation, and fault/ wrongfulness (i.e. unlawful intent and negligence).

The three grounds of attribution are so to speak the backbone of the civil law of delict. The meat on these bones is the respective national case law, developed through learned court decisions and refined by doctrinal and interdisciplinary legal scholarship. The complexity of this law of delict can no longer be presented in the text of a civil code. It is the allure of the Japanese law of delict that with 16 articles it found an exemplary compromise between the French grandeur of brevity ( 5 articles) and the German efforts of exhaustive regulation (30 paragraphs). Now, as before, the adequate path to shaping a future law of delict will be by coexistence of comprehensive regulation of the basic structures in the code, complementary legislation on specific issues, innovative judicial decisions, and the scholarly/doctrinal formulation of the entire framework in textbooks.

174 This approach has close structural ties with the basic norm Art. 1:101 of the Principles of European Tort Law (n. 98), notwithstanding remaining differences in content. Via this route, it has also found its way into $§ 1292$ para 2 of Austria's National Reform Draft. Cf. I. Griss/G. Kathrein/H. Koziol (eds), Entwurf eines neuen österreichischen Schadensersatzrechts (Vienna/New York: Springer 2006). 